\title{
Rehabilitation of a complex industrial wastewater containing heavy metals and organic solvents using low cost permeable bio-barriers - From lab-scale to pilot-scale
}

\author{
B. Silva *, V. Rocha, A. Lago, F. Costa, T. Tavares \\ CEB - Centre of Biological Engineering, University of Minho, Campus de Gualtar, 4710-057 Braga, Portugal
}

\section{A R T I C L E I N F O}

\section{Keywords:}

Industrial wastewater

Heavy metals

Ketones

Bio-barriers

Sepiolite

Biofilm

\begin{abstract}
A B S T R A C T
This work addresses the treatment of a complex industrial effluent containing high concentrations of metals and spiked with two organic solvents (diethylketone - DEK, and methyl ethyl ketone - MEK) using an eco-friendly approach. The treatment system herein proposed consists of a bio-barrier that combines the adsorption capacity of sepiolite with the properties of a Streptococcus equisimilis biofilm with proven ability in the degradation and bioremoval of a wide range of pollutants.

Results from the open-systems experiments conducted with raw sepiolite exposed to a binary mixture of DEK and MEK revealed the preference of the sorbent towards DEK. The results from the biodegradation experiments also revealed the preference of $S$. equisimilis to degrade/bioremove DEK over MEK independently of their initial concentration $(100 \mathrm{mg} / \mathrm{L}$ to $3200 \mathrm{mg} / \mathrm{L})$. Bioremoval percentages higher than $95 \%$ were reached for all the concentrations of DEK tested. The lab-scale experiments conducted in open-system with sepiolite and sepiolite covered with biofilm, and the pilot-scale experiment conducted in closed-loop, revealed similar performances on the rehabilitation of an industrial effluent containing heavy metals and additionally spiked with DEK and MEK. Regarding the selectivity towards the different pollutants, $\mathrm{Cu}$ was preferentially removed over $\mathrm{Cr}$ and $\mathrm{Ni}$, and DEK over MEK. The presence of the biofilm allowed an improvement on the removal of heavy metals, particularly $\mathrm{Cr}$, besides preventing the leaching of $\mathrm{Al}, \mathrm{Fe}$, and $\mathrm{Mg}$ from the sepiolite structure, an extremely important advantage in comparison to the system without biofilm. EDS analyses performed in sepiolite samples revealed the presence of several metals $(\mathrm{Cr}, \mathrm{Cu}$ and $\mathrm{Ni}$ ), proving thus the occurrence of sorption processes by sepiolite and by sepiolite covered by biofilm. The breakthrough data obtained in the open-systems were properly described by the Dose Response and the Yoon and Nelson mathematical models. More research work needs to be performed with complex industrial effluents aiming the optimization of the treatment systems to be applied in real context scenarios.
\end{abstract}

\section{Introduction}

The increase of surface water pollution caused by continuous and growing discharges of industrial effluents coupled with inefficient treatment is seen as one of the serious environmental problems that society faces nowadays. Numerous organic and inorganic compounds are directly released into water bodies, as well as from leachates from soils [1]. Effluents produced by industries usually contain different classes of chemicals that are introduced into the manufacturing process at different concentrations levels, closely dependent on the production volume and on the nature of the products. Heavy metals, for instance, are present in most of the raw materials used in different anthropogenic industries such as metal processing, painting industry, insecticides and other biocides production, plastic, leather, plating industries, mining, rubber and drugs processing [2,3]. Heavy metals, such as $\mathrm{Pb}, \mathrm{Hg}, \mathrm{Cr}, \mathrm{Cd}$, $\mathrm{Cu}, \mathrm{Zn}$ and $\mathrm{Ni}$, are highly toxic because of their good solubility in water, long biological half-lives, and potential to bioaccumulation. Accumulation of heavy metals in different body tissues has the potential to affect vital organs such as kidneys, bones, liver, and to cause serious health hazards [4]. Typical concentrations of heavy metals in water matrices can vary from few $\mu \mathrm{g} / \mathrm{L}$ (drinking water [5], surface water [6,7]) to thousands $\mathrm{mg} / \mathrm{L}$ (industrial wastewater $[8,9]$ ). Although attention has

\footnotetext{
* Corresponding author.

E-mail address: bsilva@deb.uminho.pt (B. Silva).
} 
been focused on individual removal of heavy metals, heavy metals usually exist together with other type of pollutants in the environment and industrial wastewater. One such example are volatile organic compounds (VOCs) that are also used in several industrial processes and manufacturing methods, playing a vital role in modern society [10]. Chemical industries use them systematically and consequently generate large quantities of organic residues $[11,12]$. Among VOCs, ketones are extensively used in food, chemicals, electronics, paint, rubbers, lubricants and pharmaceutical industries and are generally released into the environment by petrol and petrochemical industries. Although the concentrations of solvents in water are not generally high (in the order of $\mu \mathrm{g} / \mathrm{L}$ ), they can last longer in water because of their low-to-medium water solubility [13]. In the case of chemical disasters and industrial spills, the released VOC concentration in the water can be quite high (in the order of $\mathrm{g} / \mathrm{L}$ ) - enough to induce acute toxicity to aquatic organisms. The release of such solvents into the environment constitutes a threat to living beings and human health due to their high mobility; persistence in water, soil and air. As volatile organic compounds are flammable, eventually malodorous and potentially toxic to aquatic ecosystems, their complete elimination in wastewater treatment plants is crucial [14].

The reduction of the pollution load on water bodies is essential to prevent or, at least, minimize the disequilibrium of ecosystems, the significant impact on living organisms and the overall effect on public health [15]. The traditional technologies used for the elimination of odorous and toxic pollutants are incineration, ozonation, combustion, adsorption on granular activated carbon (GAC), air-stripping and biofiltration $[16,17]$. Although air-stripping and biofiltration are the most commonly used treatment techniques for the removal of organic solvents, they present very high operating and equipment costs [17]. Chemical coagulation is the most popular technique for the retention of metal ions and demonstrated to be effective in the treatment of industrial effluents. However, it can induce secondary pollution due to the addition of chemical substances, resulting in high treatment costs [18]. Adsorption is a widely known effective methodology for the removal of pollutants [19]. The large adsorption capacity of GAC makes it one of the most known and used adsorbents, but its practical usage is restricted due to its relatively high cost, especially when applied at industrial scale where it becomes completely unaffordable [20]. According to literature, distinct organic/inorganic and biological materials have been tested as adsorbents or biosorbents for the entrapment of different types of contaminants $[21,22]$. The performance of natural adsorbents such as clays has been evaluated in the treatment of aqueous solutions with different pollutants due to their availability, large surface area, low cost, chemical and mechanical stability [23-26]. In the field of wastewater treatment, many studies report the use of natural and/or modified sepiolite as an adsorbent for different water contaminants such as dyes [27], pharmaceutically active compounds [28], metal ions [29], polycyclic aromatic compounds [30], oils [31] and pesticides [32], as for other organic and inorganic pollutants [27,28,33-37].

Sepiolite is a natural hydrated magnesium silicate and has a 2:1 inverted structure with the general formula $\left(\mathrm{OH}_{2}\right)_{4}(\mathrm{OH})_{4} \mathrm{Mg}_{8}$ $\mathrm{Si}_{12} \mathrm{O}_{30} \cdot 8 \mathrm{H}_{2} \mathrm{O}$ [38]. Theoretically, sepiolite has eight possible octahedral positions, all of which are filled by $\mathrm{Mg}$. Sepiolite may however present several distinct structural formulas since some substitutions of $\mathrm{Mg}$ for $\mathrm{Al}$ and/or $\mathrm{Fe}$ are possible, which induce an increase in the number of octahedral vacancies [39]. Its structure is defined by alternation of blocks and cavities or tunnels that grow up in the fiber direction [40]. Rectangular channels contain some exchangeable $\mathrm{Ca}^{2+}$ and $\mathrm{Mg}^{2+}$ ions and two types of water: bound water (molecules coordinating with $\mathrm{Mg}$ at the broken bond surfaces of the channels) and zeolitic water (clusters filling the empty space in the channels and hydrogen-bonded to the bound water) [41]. As the silica sheets are discontinuous, silanol groups $(\mathrm{Si}-\mathrm{OH})$ are present at the border of each block in the external surface of the silicate [27].

In parallel with the exploitation of sorption processes to treat polluted matrices, the interest in biological procedures to treat industrial wastewater also increased, especially during the last decades. Biological treatments offer a cost-effective option and they are positively perceived by the general public as environment friendly alternatives to conventional rehabilitation methods [42]. Studies conducted with bacteria revealed their great potential for hazardous contaminants biodegradation and/or removal. These microorganisms have the ability to adjust to environmental changes due to the selective character of their cellular membrane and to the release of bio-products that lower the surface tension and eventually reduce the concentration of toxic compounds present inside the cells by the use of efflux pumps [43]. The structural polymers present in the cell wall provide functional groups such as carboxyl, phosphoryl and amino groups responsible for the cell membrane reactivity and for the ability of bacteria to degrade, fix and/or entrap pollutants from aquatic environment [44].

The use of clays coupled with bacteria to remove pollutants from synthetic solutions has proven its efficiency and has numerous advantages [45]. Biofilm communities provide a beneficial physical structure for the development of a microbial culture since, in this form, the culture has higher biological activity and sorption area, presenting enhanced protection against stressful conditions of the surrounding environment, improving pollutants detoxification [46]. Biofilms have also demonstrated the ability to entrap a wide range of organic pollutants and metal ions $[47,48]$, playing thus an important and decisive role in the fate of pollutants in aquatic environments [49-51].

In this context, the concept of permeable reactive bio-barriers (PRBB) rises as the most promising and widely accepted remediation technology for contaminated groundwater [52]. The development and implementation of this concept has been growing from lab to full-scale. PRBB entail the emplacement of an engineered highly permeable reactive material in the subsurface [53,54], perpendicular to groundwater flow direction [52], to treat contaminated plumes in situ transported by natural groundwater flow [55]. Target contaminants are immobilized, adsorbed and/or transformed into less toxic and harmful forms due to different physical, chemical, and biological reactions that occur in the solid support [56].

Bacteria can thus be synergistically combined in these barriers to enhance the efficiency of the rehabilitation process [52]. Biological activity in the PRBB may increase the effectiveness of the decontamination process by direct transformation of organic pollutants or accumulation/precipitation of inorganic compounds by selected microorganisms [57]. Microbial populations or their consortia should then be chosen considering the pollutant degradative ability [52,57].

Although laboratory studies with industrial effluents may be challenging, it is vital to fully understand the behavior and the interactions between different classes of pollutants, as well as the treatment performance in a real environmental context. According to an updated literature survey very few publications address the removal behavior and performance of different types of pollutants in complex industrial effluents. In this work, an industrial effluent collected from a chrome plating facility, containing high concentrations of metals $\mathrm{Ni}, \mathrm{Cr}, \mathrm{Cu}, \mathrm{Al}$, Fe, Zn) was additionally spiked with two organic solvents, methyl ethyl ketone (MEK) and diethyl ketone (DEK) that were used as model compounds. The rehabilitation ability of an eco-friendly system consisting of sepiolite covered by a $S$. equisimilis biofilm was accessed on the treatment of this industrial effluent. $S$. equisimilis was selected to be used in this work since, in previous studies, this bacterial strain has demonstrated its ability to biodegrade DEK in the presence of heavy metals $[23,47,48,58-60]$. In a first stage, lab-scale experiments were performed in order to explore the solutes interactions, as well as to identify the operational parameters to be optimized. In a second stage, a scale-up of the previous treatment systems was tested aiming the approach to a more realistic scenario. The presence of metals on the surface of sepiolite was evaluated by dispersive energy spectroscopy (EDS), whereas the removal/biodegradation of MEK and DEK was followed by gas chromatography analysis.

The present study is in line with contemporary bio-economy trends 
since it explores the use of low-cost materials and biological processes to rehabilitate complex industrial effluents.

\section{Experimental}

\subsection{Materials}

Natural sepiolite was obtained from Tolsa S.A. (Spain). According to the supplier, the raw clay corresponds to $80 \%$ of pure sepiolite and $20 \%$ of other clays, having the following composition: $\mathrm{SiO}_{2}(60.7 \%), \mathrm{Al}_{2} \mathrm{O}_{3}$ (3.1\%), $\mathrm{MgO}$ (21.8\%), $\mathrm{CaO}(1.6 \%), \mathrm{Fe}_{2} \mathrm{O}_{3}(1.0 \%), \mathrm{Na}_{2} \mathrm{O}(0.4 \%), \mathrm{K}_{2} \mathrm{O}$ $(0.9 \%)$, with all of the oxides taking part of the clay structure.

Textural properties of the sepiolite were determined at the Faculty of Science and Technology, New University of Lisbon (BET surface area of $181.35 \mathrm{~m}^{2} / \mathrm{g}$, pore volume of $0.30 \mathrm{~cm}^{3} / \mathrm{g}$ and average pore size of 65.8 $\AA$ ). Before usage, sepiolite was washed with deionized water several times to remove dirt and particulate materials and then it was dried at $50{ }^{\circ} \mathrm{C}$, after which it was ground and sieved to obtain a particle size inferior to $1 \mathrm{~mm}$ and stored in desiccator for further use. Acid-modified sepiolite was prepared by mixing natural sepiolite with $\mathrm{HNO}_{3} 2 \mathrm{M}$ at a solid-liquid ratio of $120 \mathrm{~g} / \mathrm{L}$, under constant mechanical stirring in Erlenmeyer flasks at $25{ }^{\circ} \mathrm{C}$ for $24 \mathrm{~h}$. Then, sepiolite was filtered and washed several times with deionized water and dried at $50{ }^{\circ} \mathrm{C}$ for $24 \mathrm{~h}$.

The strain Streptococcus equisimilis CECT 926 was obtained from the Spanish Type Culture Collection, University of Valencia. All the medium nutrients were of analytical grade: peptone, yeast extract, malt extract (Himedia) and glucose (Acros Organics). Brain heart infusion broth was prepared in distilled water and the $\mathrm{pH}$ was adjusted to 7 . The aqueous solutions of MEK (Fisher), DEK (Alfa Aesar), 2-methyl-1-butanol (SigmaAldrich) and $\mathrm{HNO}_{3}$ (Fisher) were purchase with the highest purity grade available and were prepared by dilution in distilled water.

Industrial wastewater without any prior treatment was collected from a local chrome plating company (Braga, Portugal) to be used as a real effluent.

\subsection{Characterization procedures}

\subsubsection{Analytical procedures}

Ketones quantification was performed by gas chromatography (GC), using a PerkinElmer Clarus ${ }^{\circledR} 580$ equipped with a flame ionization detector (FID) and a BP5 capillary column $(30 \mathrm{~m} \times 0.25 \mathrm{~mm} \times 0.25 \mu \mathrm{m})$. The operating conditions were as follows: the column was held initially at $50{ }^{\circ} \mathrm{C}$, then heated at $0.2{ }^{\circ} \mathrm{C} / \mathrm{min}$ to $52{ }^{\circ} \mathrm{C}$ and heated again at $45^{\circ} \mathrm{C}$ / min to $100{ }^{\circ} \mathrm{C}$. The injector and detector were maintained at $250{ }^{\circ} \mathrm{C}$. Helium was used as a carrier gas at a flow rate of $1 \mathrm{~mL} / \mathrm{min}$ and the injections were made in the split mode with a split ratio of $1: 20$. The concentrations of MEK and DEK were determined by comparison between the areas under the peaks of the internal standard (2-methyl-1butanol) and the areas under the peaks of the collected samples, in specific retention times. Under these conditions, the retention times for MEK and DEK were 2.7 and $3.8 \mathrm{~min}$, respectively.

Elemental analysis of industrial wastewater was performed by inductively coupled plasma optical emission spectrometry (ICP-OES). ICP-OES was used to assess the concentration of all tested metals through time in batch and column experiments. The operating conditions were as follows: radio frequency power of $1300 \mathrm{~W}$, argon plasma flow of $8 \mathrm{~L} / \mathrm{min}$, auxiliary gas flow of $0.2 \mathrm{~L} / \mathrm{min}$, nebulizer gas flow of $0.5 \mathrm{~L} / \mathrm{min}$. All the calibration solutions were prepared from a multielement ICP standard solution with a concentration of $1 \mathrm{~g} / \mathrm{L}$. All the samples were acidified with concentrated nitric acid $\left(\mathrm{HNO}_{3} 69 \%\right.$, Fisher) and filtered before being analyzed. The instrument response was periodically checked with the multi-element ICP QC standard solution (CHEM LAB) and with a blank $\left(\mathrm{HNO}_{3} 2 \%\right)$.

\subsubsection{Sepiolite characterization}

Raw sepiolite, acid-modified sepiolite and used sepiolite, obtained after adsorption/biodegradation experiments, were characterized by scanning electron microscope coupled with energy-dispersive X-ray spectroscopy (SEM-EDS). Samples were evaluated by a Phenom ProX scanning electron microscope coupled with an EDS detector (SEM-EDS, Phenom-World BV, Netherlands). All data were processed using the ProSuite software integrated with Phenom Element Identification software, allowing the quantification of the elements present in the samples, expressed either in weight or atomic concentration. Samples were observed without coating.

The $\mathrm{pH}_{\mathrm{zpc}}$ values for raw sepiolite and acid-modified sepiolite were measured: a solution of $0.01 \mathrm{M} \mathrm{NaCl}$ was prepared, previously bubbled with nitrogen in order to stabilize the $\mathrm{pH}$ by preventing the dissolution of $\mathrm{CO}_{2}$ and the $\mathrm{pH}$ was adjusted to different values ( 1 to 9) by adding diluted $\mathrm{H}_{2} \mathrm{SO}_{4}$ or $\mathrm{NaOH}$. For each $\mathrm{pH}$ value, the adsorbent $(0.10 \mathrm{~g})$ was added to $25 \mathrm{~mL}$ of $\mathrm{NaCl}$ solution in $50 \mathrm{~mL}$ conical flasks. All the flasks were sealed to avoid contact with air and left under moderate agitation (125 rpm) at $25( \pm 1){ }^{\circ} \mathrm{C}$, for $48 \mathrm{~h}$. Samples were filtered and the final filtrate $\mathrm{pH}$ was measured and plotted against the initial $\mathrm{pH}$ value. The $\mathrm{pH}$ at which the curve crossed the line $\mathrm{pH}_{\text {initial }}=\mathrm{pH}_{\text {final }}$ was taken as $\mathrm{pH}_{\mathrm{zpc}}$.

\subsection{Adsorption of ketones by sepiolite: open-system experiments}

Open-system experiments were performed to evaluate the efficiency of sepiolite as a permeable barrier in terms of ketones removal from water in continuous flow.

The setup consists of an acrylic column (height: $30 \mathrm{~cm}$, internal $\varnothing 4$ $\mathrm{cm}$ ) filled with $90 \mathrm{~g}$ of sepiolite. Binary solutions containing MEK and $\mathrm{DEK}$, at $100 \mathrm{mg} / \mathrm{L}$ each one, were fluxed upwards through the system (1 $\mathrm{mL} / \mathrm{min}$ ) for $120 \mathrm{~h}$. The concentration of solutes in the outflow was periodically assessed by GC. The $\mathrm{pH}$ was monitored during test time. The experiments were conducted in duplicate and the results are an average of duplicates.

\subsection{Biodegradation of ketones by S. equisimilis}

For the bacterial growth an Erlenmeyer flask $(250 \mathrm{~mL})$ containing 50 $\mathrm{mL}$ of Brain Heart Infusion culture medium, previously sterilized at $121{ }^{\circ} \mathrm{C}$ for $20 \mathrm{~min}$, was inoculated with $S$. equisimilis and incubated in an orbital shaker for $24 \mathrm{~h}$ at $37{ }^{\circ} \mathrm{C}$ and $150 \mathrm{rpm}$. This pre-inoculum was posteriorly added to an Erlenmeyer flask $(2 \mathrm{~L})$ containing $1 \mathrm{~L}$ of Brain Heart Infusion culture medium and left in an incubator for $48 \mathrm{~h}$ at $37{ }^{\circ} \mathrm{C}$ and $150 \mathrm{rpm}$. After this period, the biomass was centrifuged for $11 \mathrm{~min}$ (RCF $7950,18^{\circ} \mathrm{C}$ ) and the supernatant was collected on a sterile bottle for later use. The biomass pellets were re-suspended in a smaller volume of the collected medium to obtain a final biomass concentration in culture of $3.0 \mathrm{~g}_{\text {biomass }} / \mathrm{L}$. The concentration of bacterial cells on the culture medium was determined by measurement of the optical density at $620 \mathrm{~nm}$, using a UV-vis spectrophotometer. Erlenmeyer flasks (250 $\mathrm{mL}$ ) were firstly filled with $125 \mathrm{~mL}$ of DEK or MEK solutions at different initial concentrations (up to $3200 \mathrm{mg} / \mathrm{L}$ ) and then inoculated with the previous concentrated biomass. At different time intervals, a sample was taken, centrifuged at $13400 \mathrm{rpm}$ for $10 \mathrm{~min}$ and the supernatant was used for the estimation of ketones concentration. The experiments were conducted in duplicate, during 4-6 days. The results presented are an average of duplicates.

\subsection{Rehabilitation of industrial wastewater}

The performance of sepiolite, either alone or supporting a S. equisimilis biofilm, was evaluated in terms of the rehabilitation of a complex industrial effluent containing high concentrations of heavy metals and additionally spiked with MEK and DEK. At a first stage, the experiments were performed at lab-scale in open-system and afterwards a pilot test was run in closed-loop with pulse injections of MEK and DEK. The experimental procedures are described as follows. 


\subsubsection{Lab-scale columns experiments}

The ability of sepiolite and of a combined system consisting of sepiolite covered by a $S$. equisimilis biofilm to entrap heavy metals and ketones was evaluated in open system experiments at laboratory scale. An industrial wastewater collected from a chrome plating facility, previously characterized by ICP-OES, was artificially contaminated with DEK and MEK in order to reach a desired concentration of $100 \mathrm{mg} / \mathrm{L}$ of each ketone.

The experimental setup consists of four acrylic columns (height: 30 $\mathrm{cm}$, internal $\varnothing 4 \mathrm{~cm}$ ), two columns filled with $200 \mathrm{~g}$ of sepiolite and the other two with the same amount of sepiolite covered by a $S$. equisimilis biofilm. In order to prevent metals precipitation, sepiolite was previously subjected to a pre-treatment with a $2 \mathrm{M} \mathrm{HNO}_{3}$ solution that was fluxed upwards through the sepiolite bed for $24 \mathrm{~h}$ at $10 \mathrm{~mL} / \mathrm{min}$ and then washed with distilled water for another $24 \mathrm{~h}$. For two of the columns, the biofilm growth on sepiolite was promoted by passing inoculated culture medium in closed-loop for $48 \mathrm{~h}$. Then, the columns were fed with diluted culture medium for $24 \mathrm{~h}$ in closed-loop that was replaced by a new diluted culture medium for another $48 \mathrm{~h}$ period, after which the media were completely washed out.

The industrial effluent, previously enriched with MEK and DEK, was fluxed upwards through the four columns at $1 \mathrm{~mL} / \mathrm{min}$ for $96 \mathrm{~h}$. The solutes concentrations in the outflow were periodically assessed by GC and ICP-OES. The $\mathrm{pH}$ was monitored during the test time. The experiments were conducted in duplicate and the results are an average of duplicates. At the end, the columns were washed out and samples of sepiolite covered with biofilm were seeded in Petri plates with Brain Heart Infusion culture medium, in order to evaluate the viability of the bacteria after being exposed to the pollutants and to scan for the presence of microbial contaminations.

\subsubsection{Breakthrough modelling}

One of the criteria for a successful design of a fixed-bed column system for adsorption processes includes the process fitting by different models. Among the different mathematical models that can be used to describe the removal behavior of a certain pollutant, the Yoon-Nelson [63] and the Dose-Response [64] models have been selected to describe the experimental data obtained in this work.

The breakthrough equation developed by Yoon and Nelson is a simple model that describes the sorption phenomenon, usually for single or binary systems. It does not require any information regarding the sorbate characteristics and the physical properties of the bed. It assumes that the decreasing rate of the likelihood of sorption for each sorbate is proportional to the probability of sorption itself and to the probability of breakthrough [65]. Eq. (1) describes the Yoon and Nelson model:

$\frac{C}{C_{o}}=\frac{1}{1+e^{(\tau-t)^{*} K Y N}}$

where $C$ is the concentration of the effluent at the column outlet $(\mathrm{mg} / \mathrm{L})$, $C_{0}$ is the initial metal concentration $(\mathrm{mg} / \mathrm{L}), t$ is the operating time (min), $\mathrm{K}_{\mathrm{YN}}$ is the constant of Yoon-Nelson $\left(\mathrm{min}^{-1}\right)$ and $\tau$ is the time required to retain $50 \%$ of the initial adsorbate (min).

Dose Response model has been used to describe sorption processes in column and it describes the complete breakthrough curve with high accuracy. In this model, $\alpha$ is the parameter that will dictate the shape of the breakthrough curve. This model exhibits a parabola-like curve when $\alpha \leq 1$. Only when $\alpha>1$ will the breakthrough curve exhibit a sigmoidal shape more evident with the increase in $\alpha$ [66].

$\frac{C}{C_{o}}=1-\frac{1}{1+\left(\frac{c_{o}^{*} Q^{* *}}{\left.q_{0}^{*} m_{B}\right)^{\alpha}}\right.}$

where $\mathrm{Q}$ is the flow rate through the column $(\mathrm{mL} / \mathrm{min}), \mathrm{q}_{0}$ is the adsorption capacity of the bed $(\mathrm{mg} / \mathrm{g}), \mathrm{m}_{\mathrm{B}}$ is the mass of the adsorbent ( $\mathrm{g}$ ) and $\alpha$ is a dimensionless empirical parameter [67].

\subsubsection{Pilot-scale reactor experiment}

A compact polycarbonate acrylic column of $18.2 \mathrm{~L}$ with an internal diameter of $17 \mathrm{~cm}$ and a height of $80 \mathrm{~cm}$ was used as a pilot bioreactor. A maximum packing fraction of $1 / 3$ of the bioreactor was filled with sepiolite $(7 \mathrm{~kg})$.

For the biofilm preparation an Erlenmeyer flask $(250 \mathrm{~mL})$ containing $50 \mathrm{~mL}$ of Brain Heart Infusion culture medium, previously sterilized at $121{ }^{\circ} \mathrm{C}$ for $20 \mathrm{~min}$, was inoculated with $S$. equisimilis and incubated in an orbital shaker for $24 \mathrm{~h}$ at $37{ }^{\circ} \mathrm{C}$ and $150 \mathrm{rpm}$. This pre-culture was posteriorly added to an Erlenmeyer flask $(2 \mathrm{~L}$ ) containing $1 \mathrm{~L}$ of Brain Heart Infusion culture medium previously sterilized and incubated for more $48 \mathrm{~h}$ at $37{ }^{\circ} \mathrm{C}$ and $150 \mathrm{rpm}$. The Erlenmeyer flask was capped with a cotton stopper in order to allow passive aeration. The inoculum culture was then transferred to the bioreactor setup by pumping it upwards at a flow rate of $250 \mathrm{~mL} / \mathrm{min}$, during 5 days with total recirculation, in order to allow the biomass to get attached to the sepiolite surface and to form a well-developed biofilm. Once the biofilm was formed, the bed was washed out and $20 \mathrm{~L}$ of industrial effluent was pumped upwards through the bioreactor with a constant flow rate of $250 \mathrm{~mL} / \mathrm{min}$ in closed-loop ( $100 \%$ of recirculation). After 7 days, $30 \mathrm{~mL}$ of pure DEK was injected directly into the system at the bottom of the bioreactor, creating a pulse. When the removal of DEK reached approximately $80 \%$ (after 12 days), $30 \mathrm{~mL}$ of pure MEK was also pulse injected directly into the feeding system. The ketone volume added to the system aimed the desired initial concentration of each ketone $(1200 \mathrm{mg} / \mathrm{L})$ in the total volume of effluent circulating through the bed $(20 \mathrm{~L})$.

At pre-established time intervals, samples of the effluent were taken from the mixture tank, filtered and then analyzed by GC-MS and by ICPOES in order to determine, respectively, the concentration of DEK and/ or MEK and of metals through time. The $\mathrm{pH}$ of the effluent was also monitored over time. At the end, the column was washed out and samples of sepiolite were seeded in Petri plates with Brain Heart Infusion culture medium, in order to determine and evaluate the metabolic activity of the bacteria after being exposed to the pollutants.

\section{Results}

\subsection{Sepiolite characterization}

The pHzpc is an important design parameter in adsorption studies, corresponding to the $\mathrm{pH}$ value at which the net surface charge of the adsorbent becomes electrically neutral. The determination of this parameter is crucial for the evaluation of the electrostatic interactions between the target molecules and the adsorbent surface. The experimental results of pHzpc determination for raw and acid-modified sepiolite, using the $\mathrm{pH}$ drift method, are shown in Fig. 1. The pH at which the curve crosses the line $\mathrm{pH}_{\text {initial }}=\mathrm{pH}_{\text {final }}$ corresponds to the $\mathrm{pHzpc}$. As it

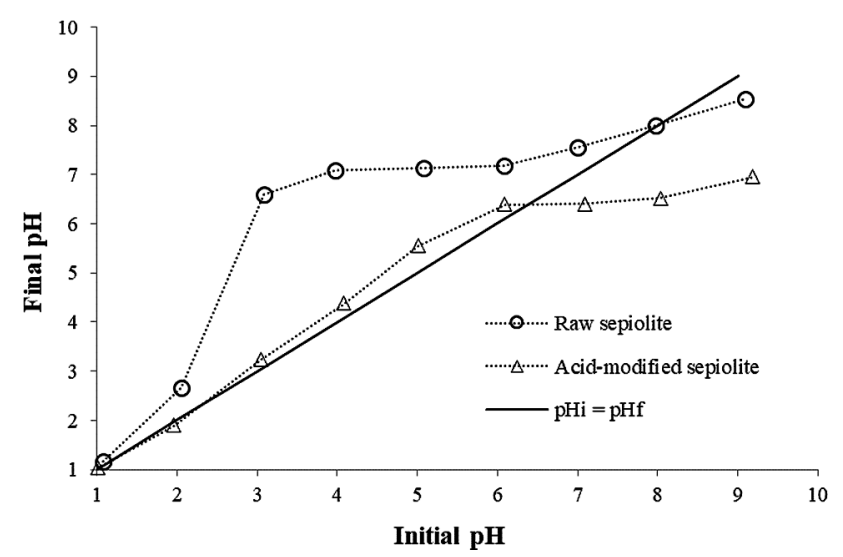

Fig. 1. Determination of pHzpc of raw sepiolite and acid-modified sepiolite using the $\mathrm{pH}$ drift method. 
can be seen, the value obtained for raw sepiolite was 8.5 , whereas for the acid-treated sepiolite the pHzpc decreased to 6.4. The acidification of the sepiolite surface was performed in order to reduce/avoid the interference of sepiolite in the precipitation of metal ions during the rehabilitation experiments.

Sepiolite samples (raw, acid-modified and taken after running the lab-scale column experiments) were analyzed by SEM (Figs. 2 and 3). It is observable that sepiolite becomes less fibrous and thus with a more polished surface after the exposure to $\mathrm{HNO}_{3} 2 \mathrm{M}$ (Fig. 2b). SEM analysis also revealed the presence of a well-established biofilm at the end of the lab-scale experiment (Fig. 3b), after $96 \mathrm{~h}$ of exposure to the industrial effluent and the two ketones. These results show the resilience of S. equisimilis, able to grow in very hazardous and toxic conditions, which is an advantage in this type of treatments. Similar results were observed by Costa and Tavares [48] when evaluating the bioremoval capacity of this bacteria towards multi-component solutions containing inorganic and organic solutes.

Sepiolite samples were evaluated according to their weighted average elemental composition (wt \%) by dispersive energy spectroscopy, EDS (Table 2). The results from this semi-quantitative analysis revealed the presence of other elements besides $\mathrm{Si}$ and $\mathrm{Mg}$, namely $\mathrm{Al}$, $\mathrm{Fe}, \mathrm{K}$ and $\mathrm{Ca}$. These results are in agreement with the characterization provided by the supplier Tolsa, S.A. The high percentages of $\mathrm{Al}$ and $\mathrm{Fe}$ found in this clay are an evidence of the significant degree of the replacement of $\mathrm{Mg}$ in the octahedral sites [68]. Small amounts of $\mathrm{Ca}$ and $\mathrm{K}$ were also found, which is very common on clays of the palygorskitesepiolite group [39]. According to this EDS analysis, after acid treatment, the percentage of $\mathrm{Si}$ increases while the contents of $\mathrm{Ca}, \mathrm{Mg}, \mathrm{Fe}$ and Al decrease. This decrease can be attributed to the dissolution of carbonated impurities and to the partial impact of the acid on the octahedral sheets containing $\mathrm{Mg}, \mathrm{Al}$ and $\mathrm{Fe}$ cations. These results are in accordance with the results reported by other authors [69].

EDS analyses performed in sepiolite samples taken at the end of the lab-scale experiments (with and without biofilm) and from the pilotscale PRBB, revealed the presence of several metals that are part of the constitution of the industrial effluent $(\mathrm{Cr}, \mathrm{Cu}$ and $\mathrm{Ni})$, proving thus the occurrence of sorption processes by sepiolite and by sepiolite covered by biofilm.

\subsection{Sorption capacity of ketones by sepiolite}

Fig. 4 shows the removal capacity of sepiolite in a column set-up, when exposed to a binary component synthetic solution (DEK and MEK, $100 \mathrm{mg} / \mathrm{L}$ each). The results are presented in normalized concentration, $\mathrm{C} / \mathrm{C}_{0}$, at the outflow, over time. The breakthrough curves showed a slow increase of the normalized concentration at the beginning, remaining below to 0.1 up to $4 \mathrm{~h}$ of experiment, which was followed by a rapid linear increase to higher $\mathrm{C} / \mathrm{C}_{0}$ values, due to the saturation of the sorbent by both ketones. From Fig. 4 is also observable that DEK is preferentially retained by sepiolite compared to MEK. At the end of the experiment, after $32 \mathrm{~h}$, the normalized concentration at the outflow was 0.775 for DEK and 0.884 for MEK.

Yoon and Nelson and Dose Response mathematical models were used to simulate the experimental breakthrough curves. The parameters obtained from the fitting of both models are presented in Table 3.

The Yoon and Nelson model was able to predict satisfactorily the adsorption breakthrough data of MEK $\left(\mathrm{R}^{2}=0.986\right)$ and DEK $\left(\mathrm{R}^{2}=\right.$ 0.970). According to this model, the time required to achieve $50 \%$ of sorbent saturation $(\tau)$ was $16.7( \pm 0.5) \mathrm{h}$ for MEK and $18.7( \pm 0.7) \mathrm{h}$ for DEK.

The Dose Response model fitted well for both MEK $\left(\mathrm{R}^{2}=0.998\right)$ and DEK $\left(\mathrm{R}^{2}=0.989\right)$ adsorption breakthrough curves. The adsorption capacity of sepiolite, $\mathrm{q}_{0}$, predicted by the Dose Response model was 15.0 $( \pm 0.2) \mathrm{mg} / \mathrm{g}$ for MEK and $17.1( \pm 0.5) \mathrm{mg} / \mathrm{g}$ for DEK.

The behavior predicted by Yoon and Nelson and by the Dose Response models is in agreement with the experimental results that showed a preference of sepiolite towards DEK, leading to a higher $\tau$ and $\mathrm{q}_{0}$ values in comparison to those obtained for MEK adsorption.

\subsection{Biodegradation potential of $S$. equisimilis}

Fig. 5 presents the concentration profile of MEK and of DEK (single component) during the biodegradation experiments performed by $S$. equisimilis. The removal percentage and maximum specific growth

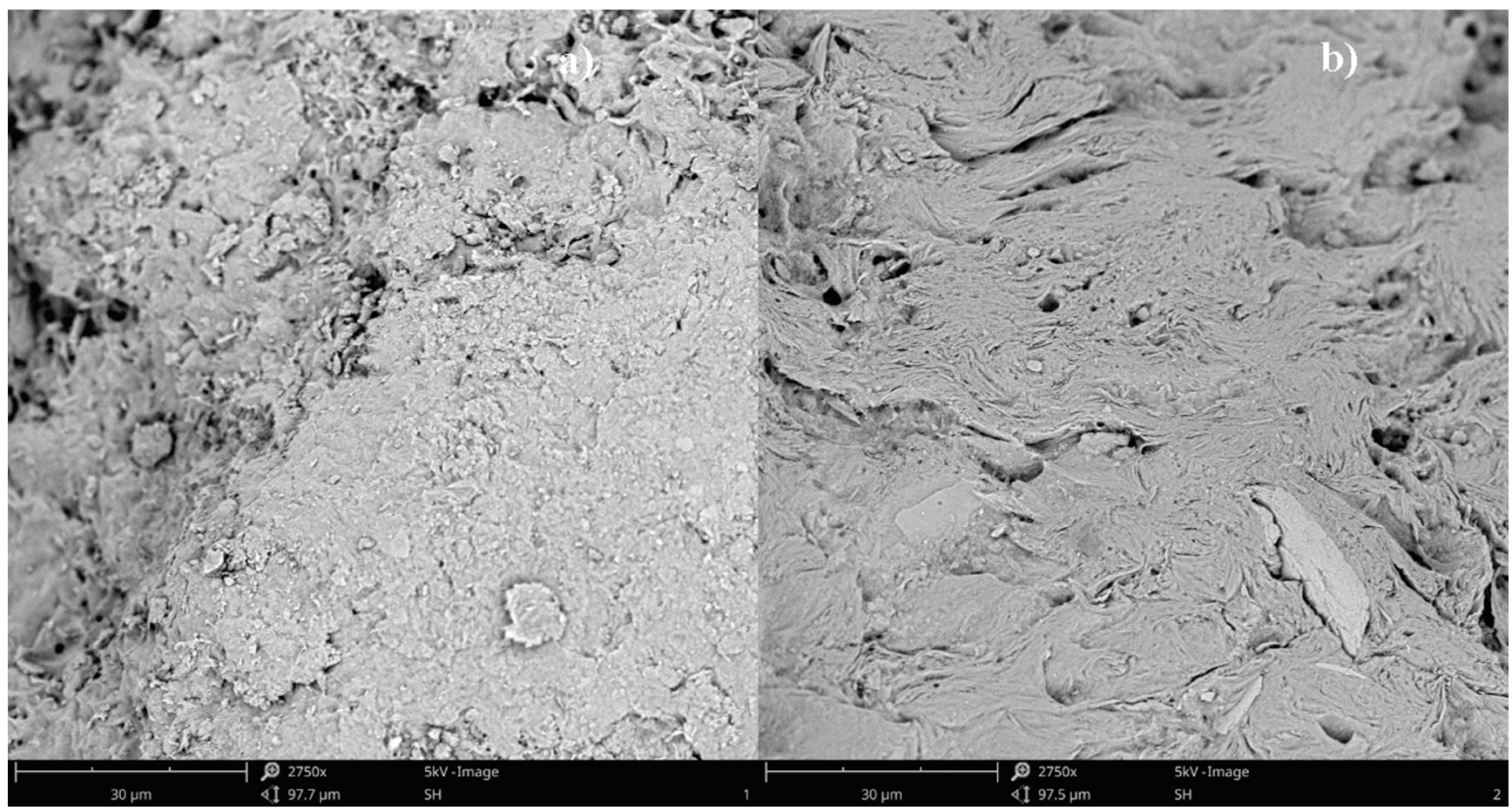

Fig. 2. SEM micrographs of raw sepiolite (a) and acid-modified sepiolite (b) after the pre-treatment with $\mathrm{HNO}_{3}$. 


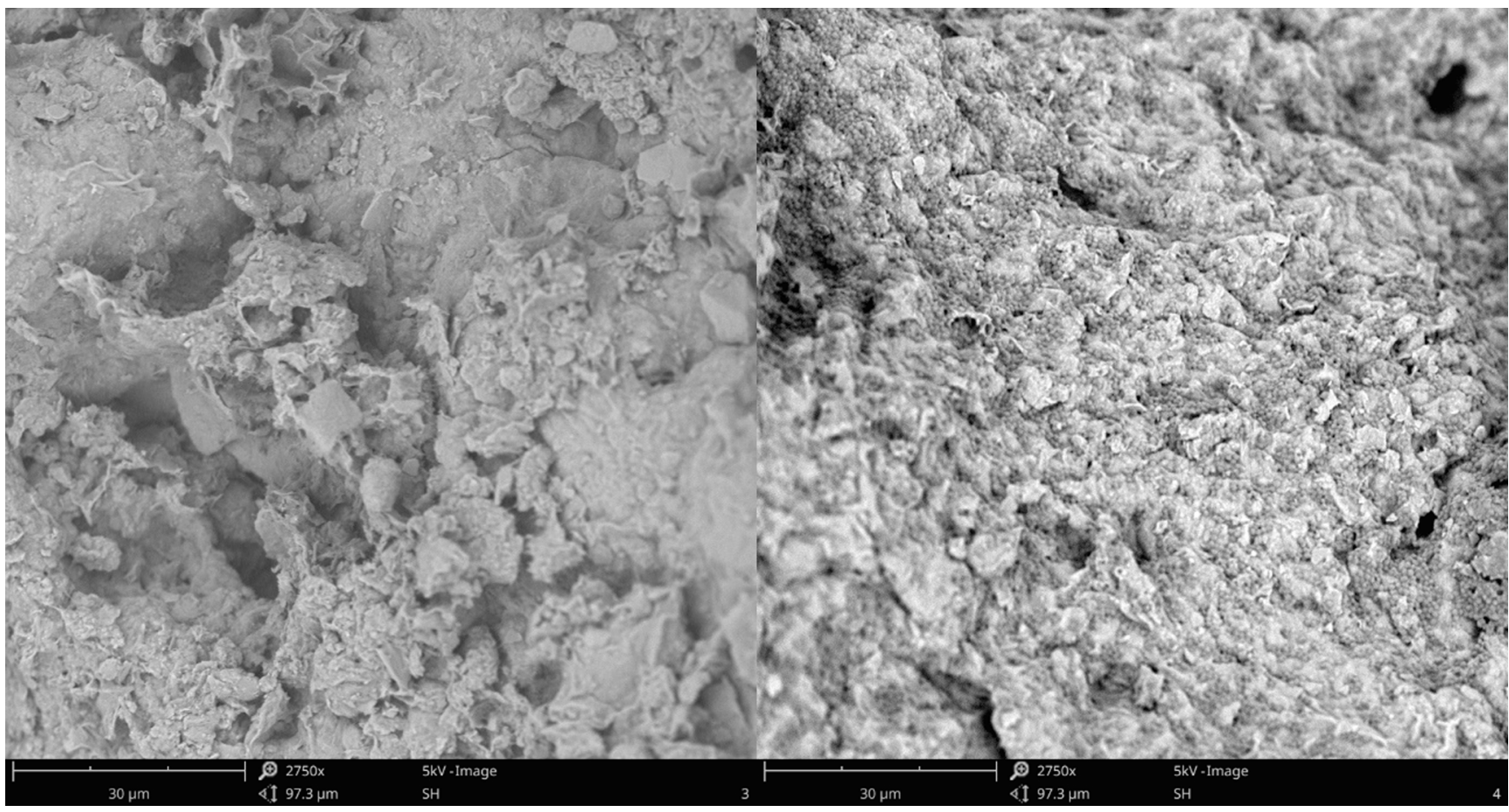

Fig. 3. SEM micrographs of sepiolite after being exposed to industrial wastewater (column experiments): sepiolite (a) and sepiolite + S. equisimilis biofilm (b).

Table 1

Properties of methyl ethyl ketone and diethyl ketone.

\begin{tabular}{|c|c|c|}
\hline Properties & $\begin{array}{l}\text { Methyl ethyl ketone } \\
\text { (MEK) }\end{array}$ & Diethyl ketone (DEK) \\
\hline Molecular formula ${ }^{1}$ & $\mathrm{C}_{4} \mathrm{H}_{8} \mathrm{O}$ & $\mathrm{C}_{5} \mathrm{H}_{10} \mathrm{O}$ \\
\hline Molecular structure $^{1}$ & 0 & 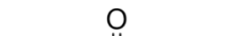 \\
\hline Molecular weight $(\mathrm{g} / \mathrm{mol})^{1}$ & 72 & 86 \\
\hline $\log \mathrm{K}_{\mathrm{ow}}^{2}$ & 0.26 & 0.99 \\
\hline $\begin{array}{l}\text { Water solubility at } 20^{\circ} \mathrm{C}(\mathrm{g} / \\
\mathrm{L})^{2}\end{array}$ & 290 & 50 \\
\hline $\mathrm{pKa}$ & $14.70^{3}$ & $19.96^{4}$ \\
\hline Boiling point $\left({ }^{\circ} \mathrm{C}\right)^{1}$ & 79.6 & 102 \\
\hline
\end{tabular}

${ }^{1}$ PubChem (www.pubchem.ncbi.nlm.nih.gov).

2 [61].

3 [62].

${ }^{4}$ ChemAxon calculator.

Table 2

Weighted average elemental composition (wt \%) of sepiolite samples (raw sepiolite, acid-modified sepiolite after $\mathrm{HNO}_{3}$ treatment and spent sepiolite taken from the lab-scale experiments and the pilot-scale PRBB.

\begin{tabular}{llllll}
\hline $\begin{array}{l}\text { Element } \\
\text { (wt \%) }\end{array}$ & $\begin{array}{l}\text { Raw } \\
\text { sepiolite }\end{array}$ & $\begin{array}{l}\text { Acid- } \\
\text { modified } \\
\text { sepiolite }\end{array}$ & $\begin{array}{l}\text { Spent } \\
\text { sepiolite } \\
\text { Lab-scale }\end{array}$ & $\begin{array}{l}\text { Spent } \\
\text { sepiolite/ } \\
\text { biofilm Lab- } \\
\text { scale }\end{array}$ & $\begin{array}{l}\text { Spent } \\
\text { sepiolite } \\
\text { Pilot-scale } \\
\text { PRBB }\end{array}$ \\
\hline $\mathrm{O}$ & 53.90 & 59.75 & 53.44 & 52.05 & 61.59 \\
$\mathrm{Si}$ & 23.10 & 29.51 & 28.45 & 26.01 & 26.89 \\
$\mathrm{Mg}$ & 9.53 & 5.82 & 5.61 & 9.28 & 8.48 \\
$\mathrm{Al}$ & 5.51 & 2.60 & 3.81 & 3.24 & 1.89 \\
$\mathrm{~K}$ & 2.16 & 1.31 & 3.51 & 1.57 & 0.57 \\
$\mathrm{Cr}$ & $\mathrm{ND}$ & $\mathrm{ND}$ & 0.23 & 0.89 & 0.03 \\
$\mathrm{Fe}$ & 5.23 & 1.16 & 3.87 & 6.44 & 0.17 \\
$\mathrm{Cu}$ & $\mathrm{ND}$ & 0.05 & 0.40 & 0.54 & 0.23 \\
$\mathrm{Ca}$ & 0.60 & 0.05 & 0.48 & 0.36 & 0.05 \\
$\mathrm{Ni}$ & $\mathrm{ND}$ & $\mathrm{ND}$ & 0.20 & 0.12 & 0.11 \\
\hline
\end{tabular}

ND - not detected.

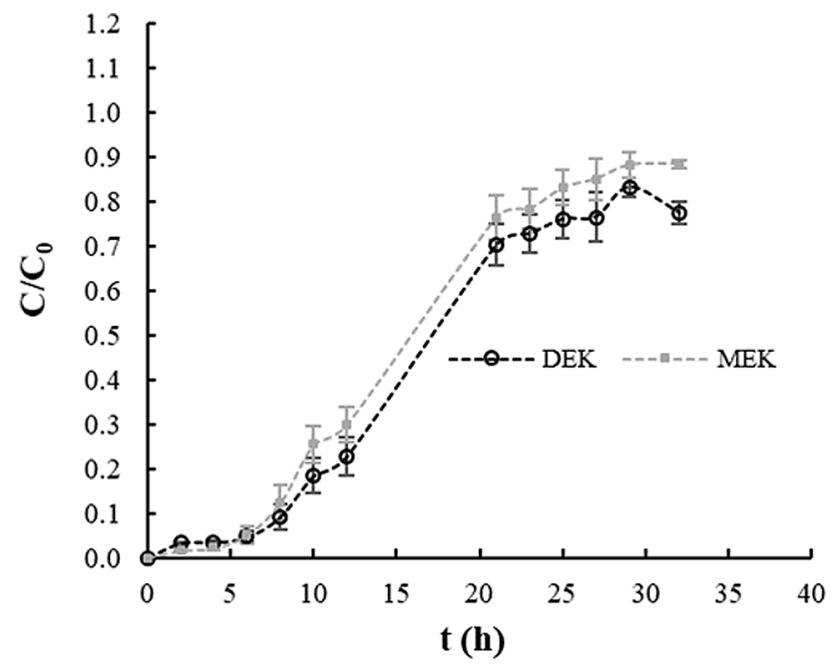

Fig. 4. $\mathrm{C} / \mathrm{C}_{0}$ for a binary component solution with MEK and DEK (100 mg/L each one) with sepiolite.

Table 3

Breakthrough parameters obtained for the adsorption of MEK and DEK by sepiolite (binary system).

\begin{tabular}{llll}
\hline Yoon-Nelson & $\mathrm{K}_{\mathrm{YN}}\left(\mathrm{h}^{-1}\right)$ & $\tau(\mathrm{h})$ & $\mathrm{R}^{2}$ \\
\hline MEK & $0.203 \pm 0.013$ & $16.7 \pm 0.5$ & 0.986 \\
DEK & $0.179 \pm 0.017$ & $18.7 \pm 0.7$ & 0.970 \\
Dose Response & $\boldsymbol{\alpha}$ & $\mathbf{q}_{\mathbf{0}}(\mathrm{mg} / \mathrm{g})$ & $\mathbf{R}^{2}$ \\
\hline MEK & $3.05 \pm 0.09$ & $15.0 \pm 0.2$ & 0.998 \\
DEK & $2.87 \pm 0.18$ & $17.1 \pm 0.5$ & 0.989 \\
\hline
\end{tabular}

rate of $S$. equisimilis attained for different initial concentrations of MEK and of DEK are represented in Fig. 6.

The concentration of DEK decreases sharply in the first hours, whereas for MEK it takes longer, particularly for the higher initial 


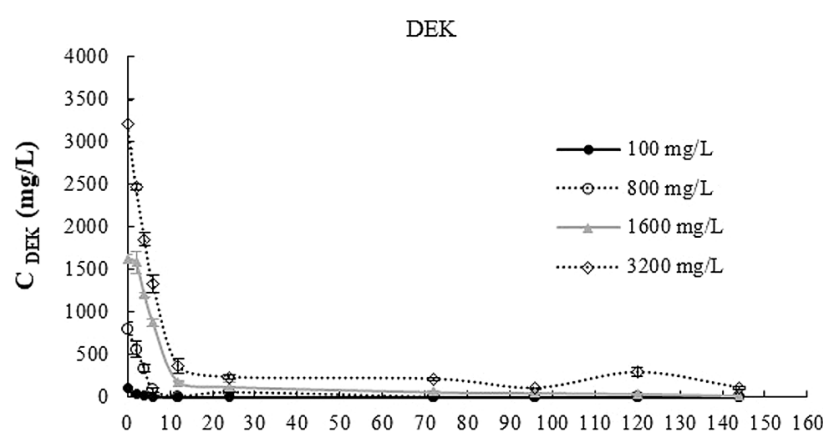

t (h)

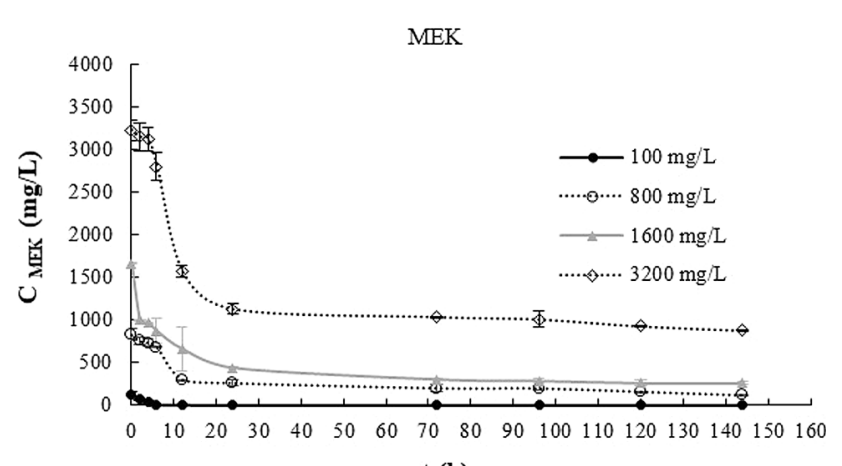

$\mathbf{t}(\mathbf{h})$

Fig. 5. Concentration profile of MEK and of DEK during the biodegradation experiments using $S$. equisimilis.

concentrations. The maximum specific growth rate $\left(\mu_{\max }\right)$ of $S$. equisimilis increases as the initial concentration of DEK increases (Fig. 6) revealing the ability of this bacteria to growth easily in the presence of this compound, even at very high concentrations, and to efficiently degrade high concentrations of DEK in a relatively short period of exposure (removal $>95 \%$ after $12 \mathrm{~h}$ for an initial concentration of $100 \mathrm{mg} / \mathrm{L}$ and after $96 \mathrm{~h}$ for the remaining concentrations). When exposed to MEK, the values of $\mu_{\max }$ of $S$. equisimilis were notably lower (Fig. 6) reaching its maximum for the initial concentration of $1600 \mathrm{mg} /$ $\mathrm{L}$, value above which the microbial growth is inhibited. The degradation was relatively slower and not as efficient, since complete degradation was achieved only for the lowest concentration, $24 \mathrm{~h}$ after the beginning of the experiment.

Two widely used kinetic models were used to describe the data from the biodegradation experiments. The fitting parameters of the pseudofirst order and of the pseudo-second order kinetic models determined for the different initial concentrations of MEK and of DEK are presented in Table 4. The results reveal that experimental data were best fitted by the pseudo-first order model for both ketones (except for MEK at 1600 $\mathrm{mg} / \mathrm{L}$ ). In general, the kinetic constant $\mathrm{k}_{1}$ tended to decrease with the raising of the initial concentration, indicating that the biodegradation rate decreases with increasing concentrations of MEK or DEK. Higher values of $k_{1}$ and $k_{2}$ were obtained for DEK in comparison to MEK, for all initial concentrations except for $1600 \mathrm{mg} / \mathrm{L}$, corroborating thus the selectivity of the bacteria towards the degradation of DEK.

\subsection{Rehabilitation of industrial effluent at lab-scale}

$6 \mathrm{~L}$ of industrial effluent collected from a chrome plating facility was previously enriched with DEK and with MEK and continuously fed to the columns at lab-scale. Due to the complexity of the liquid matrix and to some variability of the solution $\mathrm{pH}$ (Fig. 7), the effluent input was continuously characterized by ICP-OES and GC analyses. The mean values and respective standard deviation are presented in Table 5. The output concentration profiles of MEK, of DEK and of each of the selected metals under study ( $\mathrm{Cr}, \mathrm{Cu}, \mathrm{Ni}, \mathrm{Al}, \mathrm{Fe}$ and $\mathrm{Mg}$ ) are presented in Fig. 8, for the experiments with sepiolite and sepiolite covered by a $S$. equisimilis biofilm.

As it may be observed in Fig. 7, the solution $\mathrm{pH}$ values at the columns' outlet are higher in comparison to the solution $\mathrm{pH}$ of the feeding effluent ( $\mathrm{pH}=1.66 \pm 0.11$ ), which is intrinsically related to the ionexchange capacity of the sepiolite bed. For all experimental times, the $\mathrm{pH}$ values at the columns' output were higher for the system with biofilm. Since the maximum solution $\mathrm{pH}$ values were lower than 5.7, possible precipitation phenomena may be disregarded.

Mathematical models were fitted to the concentration profiles obtained for each pollutant in order to access relevant parameters needed in the design and upscale of such treatment systems. The breakthrough data were fitted by the Yoon-Nelson and Dose Response models, in order to determine the time required to retain $50 \%$ of the initial adsorbate $(\tau)$ and the adsorption capacity of the bed $\left(\mathrm{q}_{\mathrm{o}}\right)$. The breakthrough parameters and the correlation coefficients are presented in Table 6. From Fig. 8 and Table 6 and according to $\tau$ and $\mathrm{q}_{\mathrm{o}}$ calculated for each metal, the preferential order for metal removal is established as $\mathrm{Cu}>\mathrm{Cr}>\mathrm{Ni}$, for both sepiolite and sepiolite/biofilm systems.

The breakthrough curve of $\mathrm{Cu}$ showed two plateau regions and the concentration of $\mathrm{Cu}$ at the outlet did not reached the concentration of the inlet, for both treatment systems (with and without biofilm). The incomplete breakthrough of $\mathrm{Cu}$ and the two plateau regions observed may be related to other phenomena rather than adsorption, for instance to precipitation that may occur inside the sepiolite, since $\mathrm{pH}$ gradients in the sorbent are generally different from the $\mathrm{pH}$ of the bulk phase. In addition, complexation phenomena may probably occur since $\mathrm{Cu}(\mathrm{II})$ is known as one of the most effective divalent ions for binding to organic molecules [70,71]. The breakthrough curves obtained for $\mathrm{Al}$ and $\mathrm{Mg}$ did not present a common sigmoidal shape, neither for the sorption on sepiolite nor for the sorption on the combined system sepiolite/biofilm. There is an enrichment of the outlet in $\mathrm{Al}$ and in $\mathrm{Mg}$, in comparison to the respective composition of the inlet. Similarly to the effect of the acid treatment on the raw sepiolite, the contact of the sepiolite bed with the extremely acidic effluent conducts to the leaching of $\mathrm{Al}$ and $\mathrm{Mg}$ that are released into the outlet. Contrarily, the release of Fe in the first samples exiting the columns was not observed. These results may be explained by the lower content of Fe on the acid-modified sepiolite in comparison with $\mathrm{Al}$ and $\mathrm{Mg}$ contents.

The results clearly show that the presence of the biofilm enhanced the removal of $\mathrm{Cu}, \mathrm{Cr}$ and $\mathrm{Fe}$, since the values of $\tau$ and $\mathrm{q}_{0}$ are higher than those obtained with only sepiolite. Moreover, these results are supported by the EDS analyses of spent sepiolite samples collected from the experiments with and without biofilm. The average content of $\mathrm{Cu}, \mathrm{Cr}$ and Fe on the sepiolite surface were higher for the experiments with biofilm $(0.54 \% \mathrm{Cu}, 0.89 \% \mathrm{Cr}, 6.44 \% \mathrm{Fe})$ in comparison with the experiment just with sepiolite $(0.40 \% \mathrm{Cu}, 0.23 \% \mathrm{Cr}, 3.87 \% \mathrm{Fe})$.

Sepiolite and sepiolite/biofilm presented very similar behaviors in terms of Ni removal, although the content of $\mathrm{Ni}$ found in sepiolite with biofilm was lower $(0.12 \% \mathrm{Ni})$ than that found on sepiolite without biofilm $(0.20 \% \mathrm{Ni})$. In the presence of biofilm, $\mathrm{Al}$ starts to be released to the aqueous medium only after $12 \mathrm{~h}$ of experiment, while for sepiolite the leaching of $\mathrm{Al}$ starts $3 \mathrm{~h}$ after the beginning of the experiment. EDS analyses revealed a similar percentage of $\mathrm{Al}$ on sepiolite samples collected from the experiments with biofilm $(3.24 \% \mathrm{Al})$ and without biofilm $(3.81 \% \mathrm{Al})$. The beneficial effect of the presence of the biofilm was also observed on the removal of Mg. For the system with sepiolite, the concentration of $\mathrm{Mg}$ (that is not initially present in the industrial effluent) starts to increase sharply, reaching a maximum value of 385 $\mathrm{mg} / \mathrm{L}$ at $\mathrm{t}=5 \mathrm{~h}$, decreasing from that moment onwards until it reaches a constant value around $80 \mathrm{mg} / \mathrm{L}$. With the combined system sepiolite/ biofilm the concentration of $\mathrm{Mg}$ released into the outlet did not suffer significant oscillations, ranging between $95 \mathrm{mg} / \mathrm{L}$ and $124 \mathrm{mg} / \mathrm{L}$. In line with these results, EDS analyses revealed a higher content of $\mathrm{Mg}$ on 

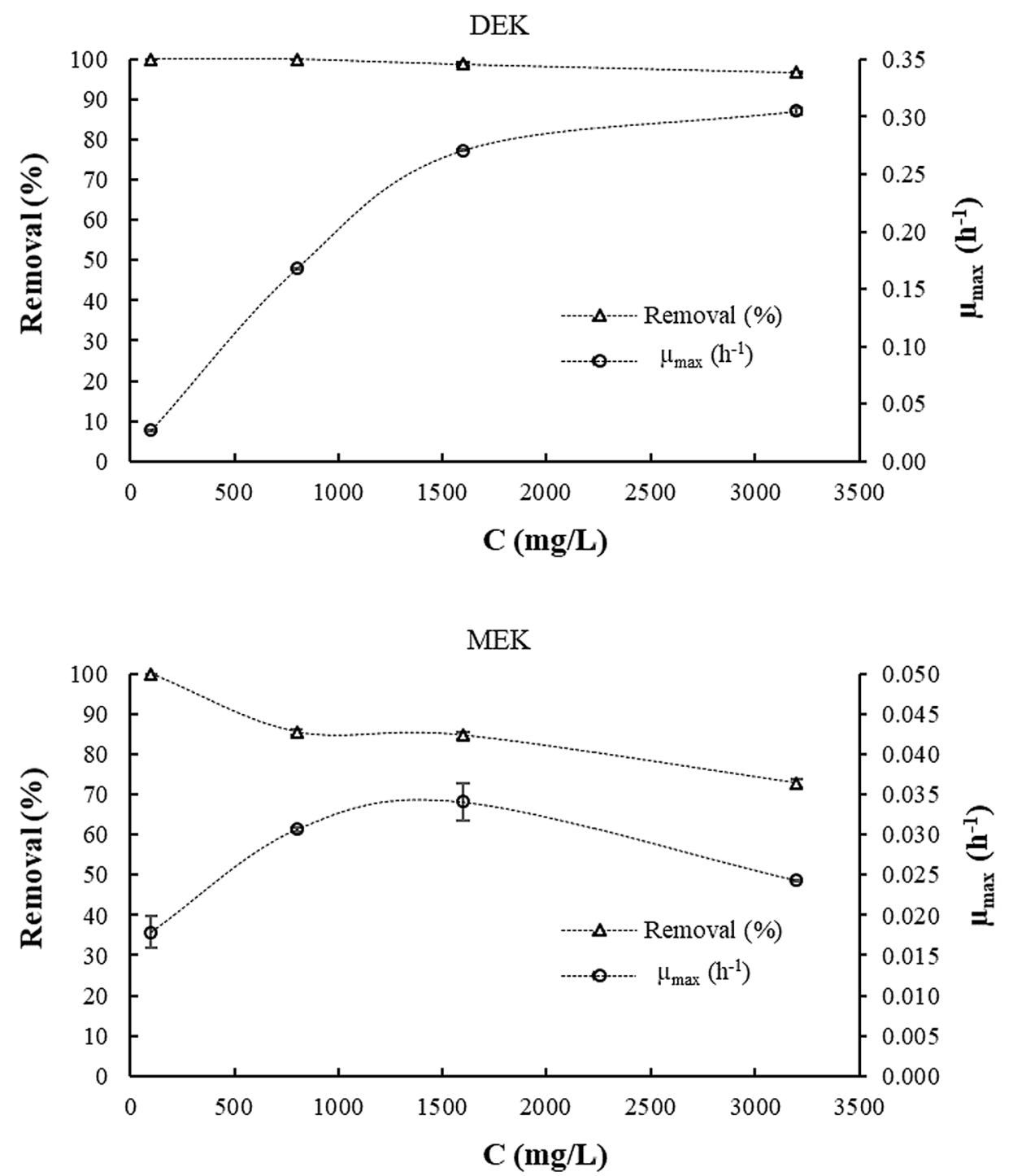

Fig. 6. Removal (\%) and maximum specific growth rate $\left(\mathrm{h}^{-1}\right)$ of $S$. equisimilis for the biodegradation experiments using different initial concentrations of DEK or MEK.

Table 4

Fitting parameters for the pseudo-first order and the pseudo-second order kinetic models determined for MEK and DEK, for the biodegradation experiments with S. equisimilis.

\begin{tabular}{|c|c|c|c|c|}
\hline \multirow{2}{*}{$\begin{array}{l}\text { Pseudo-first } \\
\text { order } \\
\text { C (mg/L) }\end{array}$} & \multicolumn{2}{|l|}{ MEK } & \multicolumn{2}{|l|}{ DEK } \\
\hline & $\mathrm{k}_{1}\left(\mathrm{~h}^{-1}\right)$ & $\mathrm{R}^{2}$ & $\mathrm{k}_{1}\left(\mathrm{~h}^{-1}\right)$ & $\mathrm{R}^{2}$ \\
\hline 100 & $0.292 \pm 0.019$ & 0.991 & $0.428 \pm 0.009$ & 0.999 \\
\hline 800 & $0.076 \pm 0.015$ & 0.943 & $0.250 \pm 0.029$ & 0.970 \\
\hline 1600 & $0.173 \pm 0.030$ & 0.924 & $0.090 \pm 0.012$ & 0.980 \\
\hline 3200 & $0.067 \pm 0.015$ & 0.934 & $0.161 \pm 0.011$ & 0.990 \\
\hline $\begin{array}{l}\text { Pseudo-second } \\
\text { order }\end{array}$ & MEK & & DEK & \\
\hline & $k_{2}$ (g/mg.h) & $\mathrm{R}^{2}$ & $k_{2}$ (g/mg.h) & $\mathrm{R}^{2}$ \\
\hline 100 & $\begin{array}{l}7.84 \times 10^{-2} \pm 1.70 \\
\times 10^{-2}\end{array}$ & 0.962 & $\begin{array}{l}2.01 \times 10^{-1} \pm 3.00 \\
\times 10^{-2}\end{array}$ & 0.987 \\
\hline 800 & $\begin{array}{l}2.33 \times 10^{-3} \pm 8.65 \\
\times 10^{-4}\end{array}$ & 0.925 & $\begin{array}{l}11.6 \times 10^{-3} \pm 3.34 \\
\times 10^{-3}\end{array}$ & 0.930 \\
\hline 1600 & $\begin{array}{l}3.76 \times 10^{-3} \pm 6.28 \\
\times 10^{-4}\end{array}$ & 0.973 & $\begin{array}{l}2.13 \times 10^{-3} \pm 7.77 \\
\times 10^{-4}\end{array}$ & 0.913 \\
\hline 3200 & $\begin{array}{l}4.79 \times 10^{-4} \pm 2.17 \\
\times 10^{-4}\end{array}$ & 0.907 & $\begin{array}{l}1.92 \times 10^{-3} \pm 4.35 \\
\times 10^{-4}\end{array}$ & 0.957 \\
\hline
\end{tabular}

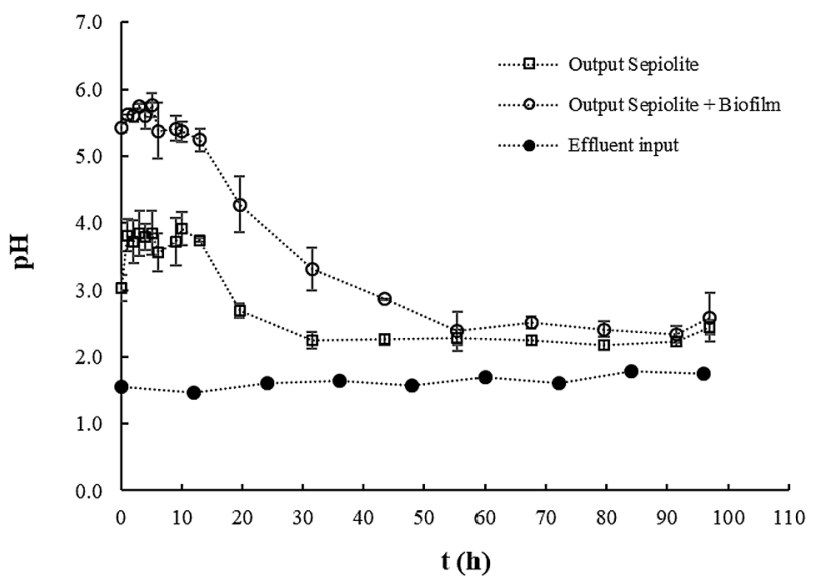

Fig. 7. pH variation of the effluent and of the column's outlet during the labscale experiments. 
Table 5

Overall composition (average value) of the industrial effluent used on the labscale experiments.

\begin{tabular}{lll}
\hline Parameter & Average value & Units \\
\hline $\mathrm{pH}$ & $1.66 \pm 0.11$ & - \\
Total Ni & $193.2 \pm 1.8$ & $\mathrm{mg} / \mathrm{L}$ \\
Total Cr & $132.7 \pm 2.3$ & $\mathrm{mg} / \mathrm{L}$ \\
Total Cu & $81.5 \pm 1.8$ & $\mathrm{mg} / \mathrm{L}$ \\
Total Al & $2.90 \pm 0.57$ & $\mathrm{mg} / \mathrm{L}$ \\
Total Ca & $195.4 \pm 3.5$ & $\mathrm{mg} / \mathrm{L}$ \\
Total Fe & $3.26 \pm 0.17$ & $\mathrm{mg} / \mathrm{L}$ \\
Total Mg & $2.54 \pm 0.40$ & $\mathrm{mg} / \mathrm{L}$ \\
Total Na & $158.9 \pm 3.6$ & $\mathrm{mg} / \mathrm{L}$ \\
Total Zn & $1.89 \pm 0.11$ & $\mathrm{mg} / \mathrm{L}$ \\
DEK & $174.8 \pm 8.9$ & $\mathrm{mg} / \mathrm{L}$ \\
MEK & $158.9 \pm 7.7$ & $\mathrm{mg} / \mathrm{L}$ \\
\hline
\end{tabular}

sepiolite samples with biofilm $(9.28 \% \mathrm{Mg})$ in comparison to the content found on sepiolite samples without biofilm $(5.61 \% \mathrm{Mg})$, due to the lesser extension of leaching when biofilm is present. The presence of the biofilm did not enhance the removal either of MEK or DEK (Table 6). In fact, the results show that in the presence of biofilm, the breakthrough time for MEK and for DEK decreased, despite that for MEK the value of $\tau$ was higher than the one for the sepiolite bed (the saturation of the sepiolite/ biofilm bed was slower). After $96 \mathrm{~h}$ of experiment, the concentration of the effluent inlet was not reached, neither for MEK nor DEK. At the end of the lab-scale experiments, viability tests were conducted revealing that $S$. equisimilis presented biological activity after $96 \mathrm{~h}$ of exposition to heavy metals and ketones. The observed microbial resistance represents therefore an important advantage for the treatment of industrial wastewater when biological processes are applied.

\subsection{Rehabilitation of an industrial effluent at pilot-scale}

For the experiments conducted at pilot-scale, $20 \mathrm{~L}$ of industrial effluent were collected from the chrome plating facility. The overall composition of the industrial effluent is presented in Table 7.

The profile of normalized concentrations $\left(\mathrm{C} / \mathrm{C}_{0}\right)$ for the selected metals $(\mathrm{Cr}, \mathrm{Ni}, \mathrm{Cu}, \mathrm{Al}, \mathrm{Fe}$ and $\mathrm{Mg}$ ) is presented in Fig. 9. The results indicate the metal removal potential of the pilot-scale PRBB, mainly for $\mathrm{Cu}, \mathrm{Cr}$ and $\mathrm{Ni}$. The metal removal order was found to be $\mathrm{Cu}>\mathrm{Cr}>\mathrm{Ni}$ and the time at which $50 \%$ of removal was reached was approximately $30 \mathrm{~h}$ for $\mathrm{Cu}$ and $113 \mathrm{~h}$ for $\mathrm{Cr}$, while for $\mathrm{Ni}$ the maximum removal percentage was $30.6 \%$, being attained after $460 \mathrm{~h}$ of experiment. The concentrations of $\mathrm{Al}, \mathrm{Fe}$ and $\mathrm{Mg}$ increase with time (Fig. 9b), becoming higher than the starting concentration of the industrial effluent $\left(\mathrm{C} / \mathrm{C}_{0}>\right.$ 1). The leaching of these metals from sepiolite, also observed during labscale experiments, is related to the extremely acid character of the industrial effluent $\left(\mathrm{pH}_{\text {initial }}=1.28\right)$. However, the concentration of $\mathrm{Fe}$ starts to decrease after $42 \mathrm{~h}$, probably due to the exhaustion of the sepiolite Fe and sorption begins to remove it from the aqueous phase. The concentration of $\mathrm{Mg}$ and $\mathrm{Al}$ increases along time, reaching equilibrium after $370 \mathrm{~h}$, when the solution $\mathrm{pH}$ also stabilizes (Fig. 10).

The ketones were added to the feed solution in pulse injections at distinct moments and it is observable that the addition of DEK $(\mathrm{t}=$ $160.5 \mathrm{~h}$ ) did not change the concentration profiles of metals, except for $\mathrm{Ni}$. $\mathrm{Cu}$ and $\mathrm{Cr}$ concentration continued to decrease after DEK's addition, whereas Ni concentration slightly increased (Fig. 9a). The addition of MEK $(t=328.5 \mathrm{~h})$ did not affect the removal of DEK, whose concentration was $440 \mathrm{mg} / \mathrm{L}$ at the time of the second pulsed addition, remaining similar during the following hours. Similarly, the concentration profiles of metals did not suffer significant changes after the pulse addition of MEK.

At the end of the experiment $(\mathrm{t}=628.5 \mathrm{~h})$, the removal percentages of the inorganic pollutants were $76.1 \%$ for $\mathrm{Fe}, 83.3 \%$ for $\mathrm{Cr}, 84.8 \%$ for $\mathrm{Cu}$ and $30.6 \%$ for Ni. For the organic pollutants, the removal was $96.0 \%$ for DEK and $86.0 \%$ for MEK.

\section{Discussion}

Industrial effluents are often composed by a wide variety of chemicals whose concentration fluctuates according to several operational parameters such as production demand, the nature of the product being produced and the reagents required for it. The industrial effluent used in this work is a complex mixture of several metals and presents a $\mathrm{pH}$ value extremely acid. The addition of DEK and of MEK, two organic solvents usually found in industrial activities such as this, aimed to increase the complexity of the matrix and to understand the physico-chemical interactions between inorganic and organic solutes. It is important to highlight that these interactions may be physical, chemical or both and may or may not occur simultaneously, suffer antagonistic or synergetic stimulus, depending on operational parameters such as $\mathrm{pH}$, temperature and the effluent composition itself. The microbial role and the metabolic pathway used in the water rehabilitation process are also extremely influenced either by the composition of the industrial effluent, either by the concentration of its individual solutes, which may lead in extreme cases to growth inhibition and microbial death.

Sepiolite structure contains pores, silanol groups $\left(\mathrm{SiH}_{3} \mathrm{OH}\right)$ and surface-active sites that possess molecular-sieving abilities, defining three types of active sorption sites: (i) replacement of $\mathrm{H}_{2} \mathrm{O}$ molecules, coordinated with $\mathrm{Mg}^{2+}$, at the edges of structural ribbons $\left(2 \mathrm{H}_{2} \mathrm{O}\right.$ molecules $/ \mathrm{Mg}^{2+}$ ); (ii) oxygen ions on the tetrahedral sheet of the ribbons; and (iii) Si-OH groups located at the external edges of the fibrous clay [72]. The sorption of neutral organic molecules may occur by interaction with neutral sites, placed at the external surface of sepiolite or by interaction with the $\mathrm{SiH}_{3} \mathrm{OH}$ groups, easily accessible to interact almost with all the sorbate molecules [73].

The adsorption results obtained with a binary solution of MEK and DEK revealed their incomplete retention during the experimental time and that sepiolite reveals some selectivity towards DEK over MEK. Since both DEK and MEK are not ionizable molecules (high pKa values, Table 1), it may be assumed that sorption occurs preferably via replacement of $\mathrm{H}_{2} \mathrm{O}$ molecules and interaction with neutral-sites and $\mathrm{SiH}_{3} \mathrm{OH}$ groups present on the clay surface.

According to Polanyi's theory (pore filling mechanism), applicable to physical adsorption on microporous and mesoporous adsorbents, the adsorbent pore volume occupied by different solutes should be similar for the same relative concentration (ratio between solute concentration and solubility) [74]. Since both ketones have the same initial concentration and the solubility of MEK is almost six-fold higher than the solubility of DEK, it is expected that the amount of MEK adsorbed will be lower in comparison to DEK. Similar observations were reported by Sotelo et al. [75]. These authors investigated the sorption capacity of activated carbon fixed beds towards aqueous single component solutions containing MEK or trichloroethene (TCE). These authors observed that TCE was better adsorbed than MEK, not due to the molecular shape of the molecules, but due to the differences in solubility as TCE is less soluble than MEK.

Biodegradation experiments revealed that $S$. equisimilis is able to efficiently grow as well as degrade, better and quicker, high concentrations of DEK, whereas when exposed to MEK, the microbial behavior and removal performance are notably different. This can be explained by the fact that DEK has a higher octanol-water partition coefficient value (typically expressed in the logarithmic form $\log K_{O W}$ ) compared to MEK (Table 1). According to Sardessai and Bhosle [76], the $\log K_{O W}$ plays a crucial and more important role in the toxicity of a solvent, than its chemical structure, since the lower the $\log K_{O W}$, the greater the toxicity of the solvent. Organic solvents with a $\log K_{O W}$ lower than 1 and shortchained (C2-C4) are toxic in high concentrations, since they are able to directly interact with the heads of the phospholipidic bilayer, whereas solvent with longer chains tend to accumulate within the cell membrane, competing with the fatty acids present. The higher the degree of accumulation of the organic solvent in the membrane, the higher its toxicity [77]. Since MEK has a $\log K_{O W}$ three-fold smaller $\left(\log K_{O W}=\right.$ 

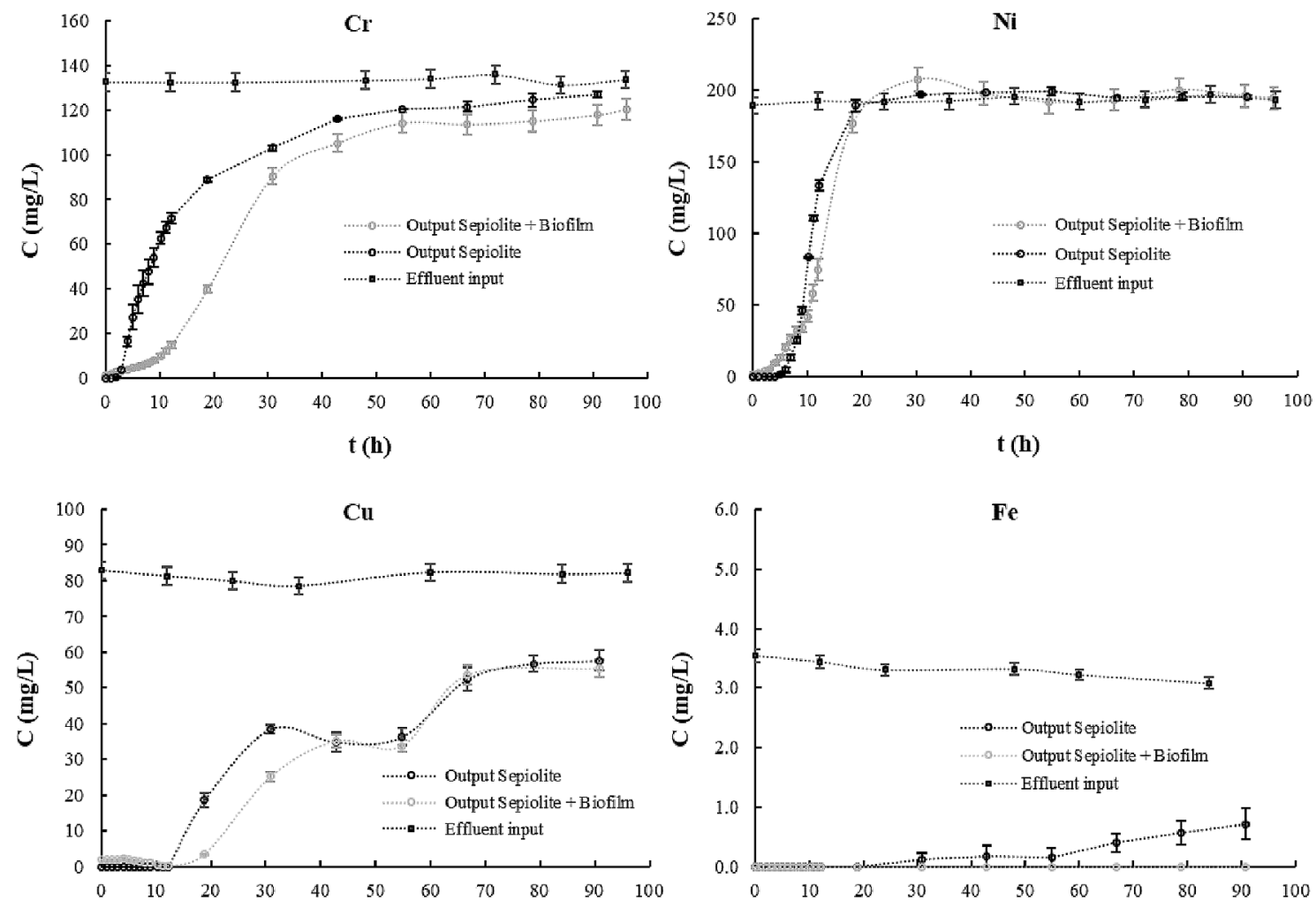

t (h)

t(h)
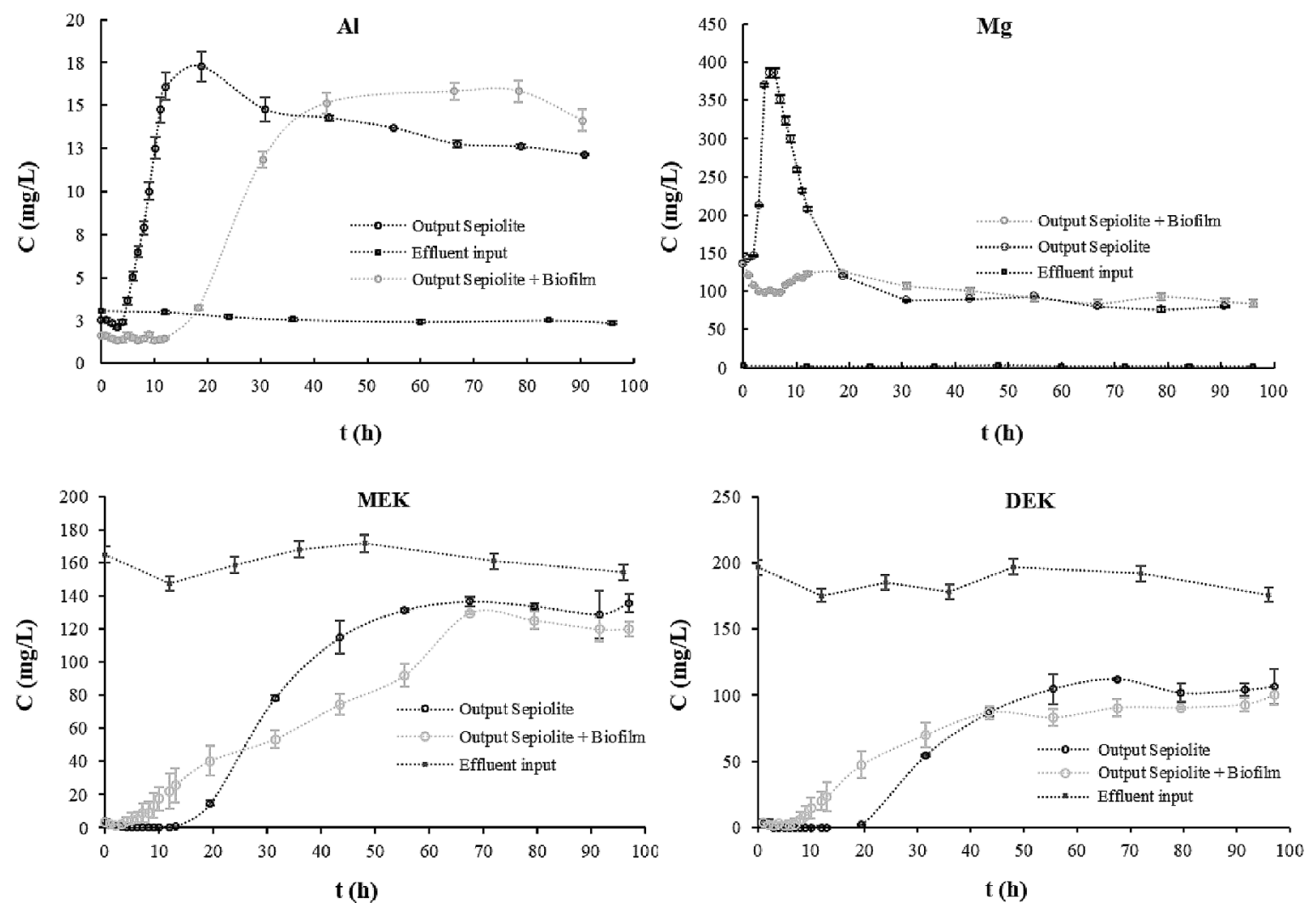

Fig. 8. Concentration profile of metals and ketones over time for the the lab-scale experiments with sepiolite and sepiolite covered by $S$. equisimilis biofilm. 
Table 6

Breakthrough parameters obtained from the fitting models for the lab-scale experiments with industrial effluent.

\begin{tabular}{|c|c|c|c|c|c|c|}
\hline \multirow[b]{2}{*}{ Yoon-Nelson } & \multicolumn{3}{|l|}{ Sepiolite } & \multicolumn{3}{|c|}{ Sepiolite + Biofilm } \\
\hline & $\mathrm{K}_{\mathrm{YN}}\left(\mathrm{h}^{-1}\right)$ & $\tau(\mathrm{h})$ & $\mathrm{R}^{2}$ & $\mathrm{~K}_{\mathrm{YN}}\left(\mathrm{h}^{-1}\right)$ & $\tau(\mathrm{h})$ & $\mathrm{R}^{2}$ \\
\hline $\mathrm{Cr}$ & $\begin{array}{l}0.208 \pm \\
0.036\end{array}$ & $\begin{array}{l}11.8 \pm \\
0.8\end{array}$ & 0.928 & $\begin{array}{l}0.129 \pm \\
0.015\end{array}$ & $\begin{array}{l}27.5 \pm \\
1.5\end{array}$ & 0.967 \\
\hline $\mathrm{Ni}$ & $\begin{array}{l}0.689 \pm \\
0.030\end{array}$ & $\begin{array}{l}10.6 \pm \\
0.1\end{array}$ & 0.998 & $\begin{array}{l}0.365 \pm \\
0.025\end{array}$ & $\begin{array}{l}13.0 \pm \\
0.2\end{array}$ & 0.996 \\
\hline $\mathrm{Cu}$ & $\begin{array}{l}0.052 \pm \\
0.007\end{array}$ & $\begin{array}{l}57.7 \pm \\
3.7\end{array}$ & 0.865 & $\begin{array}{l}0.050 \pm \\
0.007\end{array}$ & $\begin{array}{l}59.2 \pm \\
4.0\end{array}$ & 0.840 \\
\hline MEK & $\begin{array}{l}0.131 \pm \\
0.020\end{array}$ & $\begin{array}{l}34.5 \pm \\
1.7\end{array}$ & 0.963 & $\begin{array}{l}0.069 \pm \\
0.006\end{array}$ & $\begin{array}{l}40.1 \pm \\
1.7\end{array}$ & 0.972 \\
\hline DEK & $\begin{array}{l}0.085 \pm \\
0.012\end{array}$ & $\begin{array}{l}41.0 \pm \\
2.6\end{array}$ & 0.944 & $\begin{array}{l}0.103 \pm \\
0.016\end{array}$ & $\begin{array}{l}28.4 \pm \\
2.3\end{array}$ & 0.927 \\
\hline $\begin{array}{l}\text { Dose } \\
\text { Response }\end{array}$ & $\alpha$ & $\begin{array}{l}\mathrm{q}_{0} \\
(\mathrm{mg} / \mathrm{g})\end{array}$ & $\mathbf{R}^{2}$ & $\alpha$ & $\begin{array}{l}\mathrm{q}_{0} \\
(\mathrm{mg} / \mathrm{g})\end{array}$ & $\mathrm{R}^{2}$ \\
\hline $\mathrm{Cr}$ & $\begin{array}{l}1.59 \pm \\
0.07\end{array}$ & $\begin{array}{l}11.7 \pm \\
0.3\end{array}$ & 0.993 & $\begin{array}{l}2.37 \pm \\
0.13\end{array}$ & $\begin{array}{l}26.0 \pm \\
0.9\end{array}$ & 0.991 \\
\hline $\mathrm{Ni}$ & $\begin{array}{l}6.72 \pm \\
0.25\end{array}$ & $\begin{array}{l}10.5 \pm \\
0.1\end{array}$ & 0.999 & $\begin{array}{l}4.63 \pm \\
0.53\end{array}$ & $\begin{array}{l}12.7 \pm \\
0.4\end{array}$ & 0.989 \\
\hline $\mathrm{Cu}$ & $\begin{array}{l}1.75 \pm \\
0.19\end{array}$ & $\begin{array}{l}49.7 \pm \\
3.0\end{array}$ & 0.951 & $\begin{array}{l}2.00 \pm \\
0.35\end{array}$ & $\begin{array}{l}55.0 \pm \\
4.4\end{array}$ & 0.877 \\
\hline MEK & $\begin{array}{l}3.07 \pm \\
0.29\end{array}$ & $\begin{array}{l}33.5 \pm \\
1.3\end{array}$ & 0.984 & $\begin{array}{l}1.88 \pm \\
0.14\end{array}$ & $\begin{array}{l}32.5 \pm \\
1.7\end{array}$ & 0.977 \\
\hline DEK & $\begin{array}{l}2.63 \pm \\
0.29\end{array}$ & $\begin{array}{l}36.0 \pm \\
1.9\end{array}$ & 0.975 & $\begin{array}{l}1.90 \pm \\
0.12\end{array}$ & $\begin{array}{l}26.0 \pm \\
1.2\end{array}$ & 0.983 \\
\hline
\end{tabular}

Table 7

Overall composition of the industrial effluent used in the pilot-scale experiments.

\begin{tabular}{lll}
\hline Parameter & Value & Units \\
\hline $\mathrm{pH}$ & 1.28 & - \\
Total Ni & 186.5 & $\mathrm{mg} / \mathrm{L}$ \\
Total $\mathrm{Cr}$ & 551.9 & $\mathrm{mg} / \mathrm{L}$ \\
Total $\mathrm{Cu}$ & 118.4 & $\mathrm{mg} / \mathrm{L}$ \\
Total $\mathrm{Al}$ & 11.0 & $\mathrm{mg} / \mathrm{L}$ \\
Total $\mathrm{Ca}$ & 821.1 & $\mathrm{mg} / \mathrm{L}$ \\
Total Fe & 6.20 & $\mathrm{mg} / \mathrm{L}$ \\
Total $\mathrm{Mg}$ & 11.7 & $\mathrm{mg} / \mathrm{L}$ \\
Total $\mathrm{Na}$ & 1436 & $\mathrm{mg} / \mathrm{L}$ \\
\hline
\end{tabular}

0.26) than DEK ( $\left.\log K_{O W}=0.99\right)$, it is expected that this solvent has a much higher toxic potential, adversely affecting the microbial growth. This fact was verified experimentally since during the biodegradation experiments microbial flocculation was observed, $24 \mathrm{~h}$ after the beginning of the experiments, for initial concentrations of MEK higher than $800 \mathrm{mg} / \mathrm{L}$. The occurrence of microbial flocculation reveals an evident sign of microbial stress towards the environmental conditions to which they are exposed. As a result of microbial stress, lower growth rates are reached and a smaller amount of pollutant is used as substrate, leading to a lower removal performance (Fig. 6) and lower degradation rates (Table 4). Although the number of solvent-tolerant bacteria has increased significantly since the first discovery of solvent-tolerant bacteria, Pseudomonas putida IH- 2000 by Inoue and Horikoshi [78], little is yet known regarding solvent tolerance mechanisms. It is important to highlight that the toxicity of a compound towards an organism cannot be purely determined by its relative water solubility. The presence of toxic compounds may have significant impact on cellular activities since these activities are driven by enzymes, which activity can be negatively impacted due to interactions of pollutants with their proteinaceous molecular structure. In the case of certain enzymes, high concentrations of either the substrate or byproducts can be inhibitory. This phenomenon is referred to as substrate inhibition, and it is estimated that it occurs in some $20 \%$ of enzymes $[79,80]$. This may partially explain the different degradation performances and profiles of DEK and MEK.

During the biodegradation of DEK it was possible to observe the formation of three intermediates which were identified as methyl-

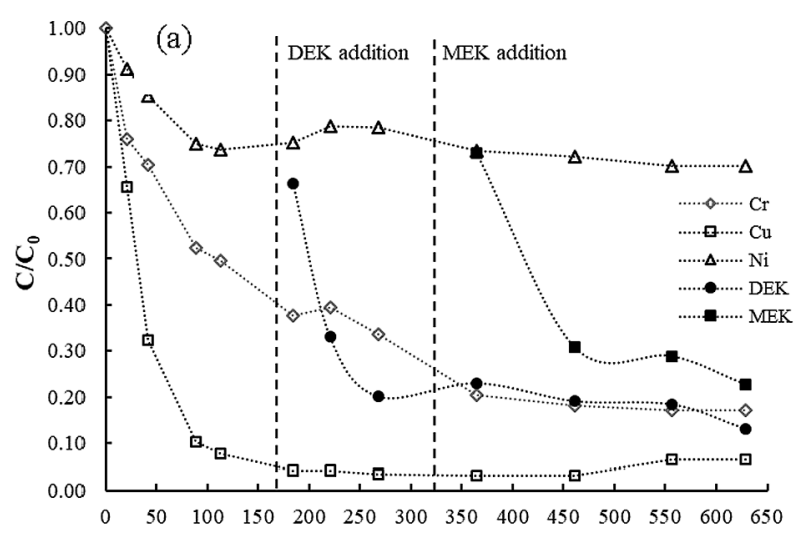

t(h)

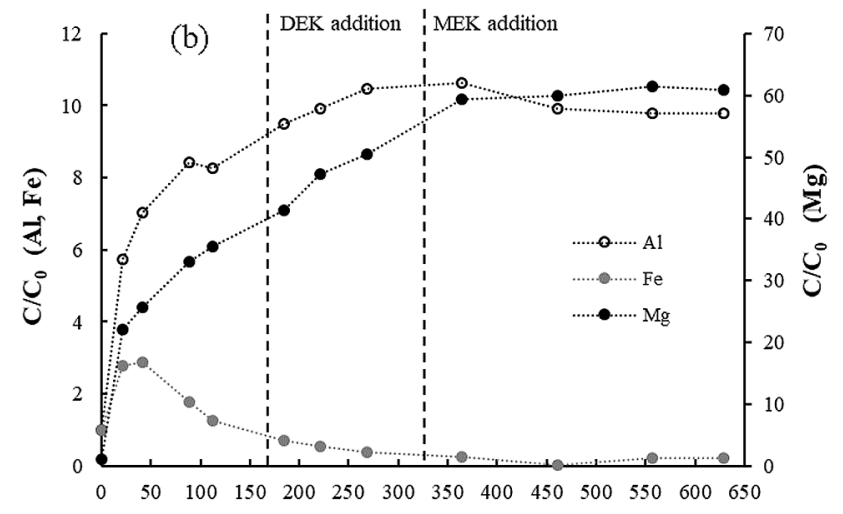

t(h)

Fig. 9. Concentration profile of $\mathrm{Cr}, \mathrm{Cu}, \mathrm{Ni}, \mathrm{MEK}, \mathrm{DEK}$ (a) and $\mathrm{Al}, \mathrm{Fe}$ and $\mathrm{Mg}$ (b) present in the industrial effluent over time.

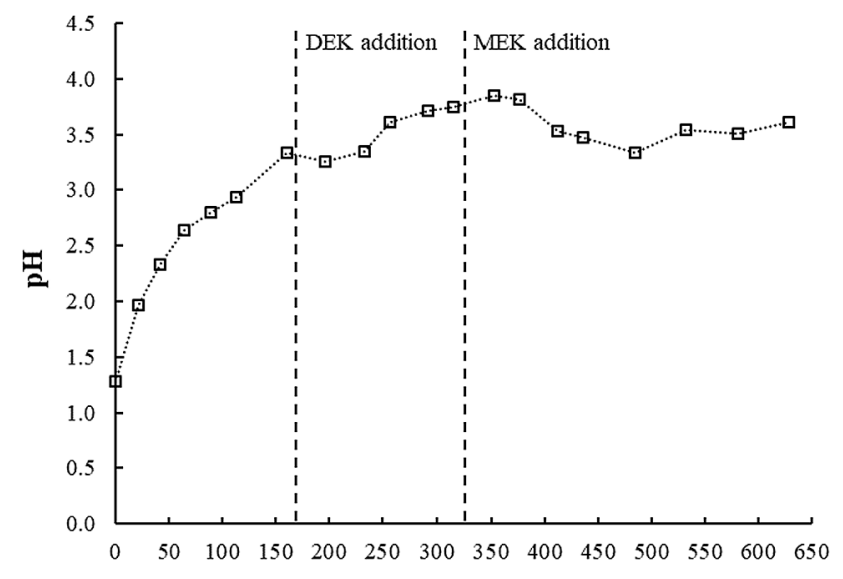

t (h)

Fig. 10. $\mathrm{pH}$ variation in the feed mixture tank during the pilotscale experiment.

acetate, ethyl acetate and 2-pentanone. Initially, the concentration of these intermediates increased being then totally consumed by the concentrated biomass. The presence and identification of the intermediates allowed an approach to the metabolic degradation pathway of DEK by $S$. equisimilis. Although the presence of 2-pentanone only represents a change on the carbon atom where the ketone group is attached to, the formation of methyl-acetate and ethyl acetate proves the occurrence of biodegradation, since both compounds have lower number of carbons in comparison to DEK. Therefore, the following 
mechanism is proposed: DEK is firstly degraded as ethyl acetate and in a second stage as methyl acetate, being these intermediates sequentially degraded by the bacteria.

During the biodegradation of MEK, it was possible to observe the formation of two intermediates (not yet identified) that were completely degraded by the bacteria. The degradation of the intermediates formed is of the utmost importance, as the toxicity and persistence of the intermediates formed during the degradation of certain chemical compounds, can be higher than the parent compound [58].

The affinity of metals or organic solvents towards an adsorbent, depending on whether the adsorption is physical, chemical and/or electrostatic, and parameters such as $\mathrm{pH}$, temperature, ionic strength, ionic size, hydrated radius, electronegativity and standard reduction potential, among others, may explain the relative order of sorbate adsorption. It may indicate the sorbates that preferably will be sorbed or that are expected to be displaced in the presence of other more competitive sorbates [81]. So, the treatment of industrial effluents with high complexity is determined by a combination of parameters with distinct relevance that may account for the competitive sorption success of a specific sorbate and therefore numerous factors may explain the competitive sorption behavior of different sorbates.

In the rehabilitation experiments conducted at lab-scale, it was observed that both treatment systems (with and without biofilm) presented the following preferential sorption order $\mathrm{Cu}>\mathrm{Cr}>\mathrm{Ni}$, explained by the determinant role of the hydrated radius of these metals ( $\mathrm{Cu} 0.295$ $\mathrm{nm}, \mathrm{Cr} 0.413 \mathrm{~nm}$ and $\mathrm{Ni} 0.425 \mathrm{~nm}$ ) and by the initial concentrations of each solute in the effluent (Table 5). The system composed by the biofilm supported in sepiolite presented, in general, a better sorption performance for $\mathrm{Cu}, \mathrm{Cr}$ and $\mathrm{Fe}$ and decreased/delayed the leaching of $\mathrm{Al}$ and $\mathrm{Mg}$ from the sepiolite structure to the aqueous matrix. The beneficial effect of the biofilm on metals removal can be attributed to their sorption by the functional groups present on the biomass (biosorption). Some of the main functional groups responsible for sorption processes (imidazole, hydroxyl, sulfonate, phosphodiester, phosphonate, amide, carbonyl and carboxyl) are present on the surface of Streptococcus sp. and therefore justify the biosorption of toxic elements such as metals [82]. Moreover, some metals ions such as $\mathrm{Fe}, \mathrm{Cu}, \mathrm{Zn}, \mathrm{Mg}, \mathrm{Mn}$ and $\mathrm{Ni}$ are involved in many crucial biological processes such as microbial growth, reproduction and metabolic activity [83]. Therefore, trace amounts of these metals are removed from the liquid medium in order to fulfill the cellular requirements of $S$. equisimilis biofilm, although the contribution of this phenomena to the overall removal of metals can be considered as residual in comparison to the uptake attained by biosorption process. Contrary to the refer metals, $\mathrm{Al}$ does not play a known biological role, although it can bind to the hydrophilic heads of the phospholipid layer and modify transport activity and lipid-protein interactions, competing and substituting magnesium [84] and iron [85] in biological systems due to its high association constant with several ligands (ATP, for example).

Incomplete breakthrough was observed for MEK and DEK during the experiments conducted at lab-scale for both treatment systems. Even though the outlet concentration values did not reached the values of the inlet, an eventual saturation of the sorbent may have occurred. In fact, the difference between the inlet and outlet concentration can be due to other phenomena distinct from adsorption, namely reaction and/or degradation in the liquid phase. The removal of ketones during the labscale experiments was more efficient with sepiolite without biofilm. Although $S$. equisimilis is able to degrade high concentrations of MEK and of DEK, as demonstrated by the biodegradation tests, the presence of the biofilm did not enhance the removal and/or biodegradation of these compounds. The insufficient contact time between the biofilm and the organic molecules may justify the obtained results.

The results obtained with the pilot-scale PRBB are coherent with the results previously obtained for the lab-scale open system regarding the preferred order for metals removal $(\mathrm{Cu}>\mathrm{Cr}>\mathrm{Ni})$. Once again, the hydrated radius ( $\mathrm{Cu} 0.295 \mathrm{~nm}, \mathrm{Cr} 0.413 \mathrm{~nm}$ and $\mathrm{Ni} 0.425 \mathrm{~nm}$ ) plays a more determinant role in the sorption process in comparison to the effect of the atomic radius ( $\mathrm{Cu} 128 \mathrm{pm}, \mathrm{Cr} 140 \mathrm{pm}$ and Ni $124 \mathrm{pm}$ ), Pauling electronegativity (Cu $1.90 \mathrm{eV}, \mathrm{Cr} 1.66 \mathrm{eV}$ and $\mathrm{Ni} 1.91 \mathrm{eV}$ ) and even the ionic strength of each sorbate. It was also observed the release of $\mathrm{Al}$ and Fe from the sepiolite bed to the aqueous phase. The results show that the concentration of $\mathrm{Al}$ continuously increases until the addition of MEK. When this ketone is added to the PRBB, Al concentration starts to slightly decrease, stabilizing around $100 \mathrm{~h}$ after the addition of MEK. Regarding $\mathrm{Fe}$, after being leached at the beginning of the experiment due to the extremely acidic character of the effluent, it starts to be removed at $\mathrm{t}=50 \mathrm{~h}$. Although the removal of Fe can be due to sepiolite and/or biofilm action, the comparison of these results with the ones obtained in the lab-scale experiments (with and without biofilm) indicates that the removal of Fe is mainly due to the biofilm action. With respect to $\mathrm{Mg}$, its concentration in solution also increased significantly due to its release from the sepiolite structure, similarly to Fe and Al. Comparing these results with the ones obtained in the lab-scale experiments, supports that $\mathrm{Mg}$ is released to a greater extent without the biofilm. Finally, DEK was once again preferentially bioremoved (sorbed and/or biodegraded) in comparison to MEK. These results are in agreement with the results obtained from the lab-scale experiments and can be explained by the higher $\log K_{O W}$ value of DEK, which is responsible for its lower solubility in water and higher hydrophobicity.

Although there is a growing number of studies regarding the removal of heavy metals and organic contaminants using different treatment technologies [86], very few publications address the simultaneous removal of different types of pollutants in real context scenarios, such as complex industrial effluents. Among the different strategies adopted for the simultaneous removal of heavy metals and organic pollutants that have been reported in literature, namely adsorption processes $[87,88]$, photocatalysis $[89,90]$, electroremediation $[91,92]$ and biological processes $[46,93]$, the last present important advantageous due to the possibility for heavy metals recovery, cost-effectiveness and regeneration of the biosorbents used [94]. Although the use of biological processes is associated with some limitations, for instance not all microorganisms have the ability to breakdown any pollutants, as well as the inhibition of growth due to the presence of toxic pollutants, in this work that limitations were overcome since the developed permeable bio-barrier revealed to be efficient on the simultaneous removal of ketones and heavy metals.

\section{Conclusions}

The column experiments conducted in continuous flow at lab-scale showed to be efficient for the treatment of industrial effluents of high complexity and containing high concentrations of organic and inorganic pollutants. The scale-up to a pilot PRBB experiment, operated in closedloop, validates the robustness and effectiveness of the treatment process, that was able to retain $\mathrm{Cu}, \mathrm{Cr}$, DEK and MEK with removal percentages higher than $80 \%$.

For both lab-scale and pilot-scale experiments the preferred metal removal order was $\mathrm{Cu}>\mathrm{Cr}>\mathrm{Ni}$ being the hydrated radius the preponderant property accountable for this observation. Regarding the organic compounds, DEK was preferred over MEK by the different sorbents employed (sepiolite and bacteria supported on sepiolite) due to its physical-chemical properties such as lower solubility and higher log $K_{O W}$ value responsible for its hydrophobicity.

The presence of the biofilm improved the removal performance of $\mathrm{Cr}$, $\mathrm{Cu}$ and $\mathrm{Fe}$, as well decreased the leaching of $\mathrm{Al}$ and $\mathrm{Mg}$ from the sepiolite structure, which stands as an important benefit in comparison to the system without biofilm.

More research work needs to be performed with complex industrial effluents in order to better understand the interactions established between the different classes of pollutants, aiming the optimization of the treatment systems to be applied in real context scenarios. 


\section{CRediT authorship contribution statement}

Bruna Silva: Conceptualization, Methodology, Investigation, Writing - original draft. Verónica Rocha: Investigation, Methodology. Ana Lago: Investigation, Methodology. Filomena Costa: Investigation, Methodology, Writing - original draft. Teresa Tavares: Supervision, Project administration, Funding acquisition, Writing - review \& editing.

\section{Declaration of Competing Interest}

The authors declare that they have no known competing financial interests or personal relationships that could have appeared to influence the work reported in this paper.

\section{Acknowledgments}

This study was supported by the Portuguese Foundation for Science and Technology (FCT) under the scope of the research project PTDC/ AAG-TEC/5269/2014, the strategic funding of UID/BIO/04469/2020 unit and BioTecNorte operation (NORTE-01-0145-FEDER-000004) funded by the European Regional Development Fund under the scope of Norte2020 - Programa Operacional Regional do Norte, Portugal. A. Lago and V. Rocha, thank FCT for the concession of their PhD grants (SFRH/ BD/132271/2017 and SFRH/BD/141073/2018).

\section{References}

[1] S. Wierzba, A. Kłos, Heavy metal sorption in biosorbents - Using spent grain from the brewing industry, J. Clean. Prod. 225 (2019) 112-120, https://doi.org/ 10.1016/J.JCLEPRO.2019.03.286.

[2] P. Chakravarty, N. Sen Sarma, H.P. Sarma, Biosorption of cadmium(II) from aqueous solution using heartwood powder of Areca catechu, Chem. Eng. J. 162 (2010) 949-955, https://doi.org/10.1016/J.CEJ.2010.06.048.

[3] D. Palin, K.B. Rufato, G.A. Linde, N.B. Colauto, J. Caetano, O. Alberton, D.A. Jesus, D.C. Dragunski, Evaluation of $\mathrm{Pb}$ (II) biosorption utilizing sugarcane bagasse colonized by Basidiomycetes, Environ. Monit. Assess. 188 (2016) 279, https://doi. org/10.1007/s10661-016-5257-8.

[4] B. Wu, Chapter 6 - Human health hazards of wastewater, in: H. Ren, X.B.T.-H.-R.P, W. Zhang (Eds.), Elsevier, 2020, pp. 125-139. https://doi.org/10.1016/B978-012-816448-8.00006-X.

[5] S. Chowdhury, M.A.J. Mazumder, O. Al-Attas, T. Husain, Heavy metals in drinking water: Occurrences, implications, and future needs in developing countries, Sci. Total Environ. 569-570 (2016) 476-488, https://doi.org/10.1016/j. scitotenv.2016.06.166.

[6] J.P. Vareda, A.J.M. Valente, L. Durães, Assessment of heavy metal pollution from anthropogenic activities and remediation strategies: A review, J. Environ. Manage. 246 (2019) 101-118, https://doi.org/10.1016/j.jenvman.2019.05.126.

[7] I. Karaouzas, N. Kapetanaki, A. Mentzafou, T.D. Kanellopoulos, N. Skoulikidis, Heavy metal contamination status in Greek surface waters: A review with application and evaluation of pollution indices, Chemosphere 263 (2021) 128192 https://doi.org/10.1016/j.chemosphere.2020.128192.

[8] E. Bazrafshan, L. Mohammadi, A. Ansari-Moghaddam, A.H. Mahvi, Heavy metals removal from aqueous environments by electrocoagulation process- a systematic review, J. Environ. Heal. Sci. Eng. 13 (2015) 74, https://doi.org/10.1186/s40201015-0233-8.

[9] V.S. Kumar, K. Vinita, S.A. K., Removal of chromium from electroplating industry effluent using electrocoagulation, J. Hazardous, Toxic, Radioact. Waste. 17 (2013) 146-152. https://doi.org/10.1061/(ASCE)HZ.2153-5515.0000170.

[10] L. Cseri, M. Razali, P. Pogany, G. Szekely, Organic solvents in sustainable synthesis and engineering, in: Green Chem., Elsevier, 2018, pp. 513-553, https://doi.org/ 10.1016/B978-0-12-809270-5.00020-0.

[11] L. Dsikowitzky, J. Schwarzbauer, Pollutant diseases, Remediat. Recycl. (2013), https://doi.org/10.1007/978-3-319-02387-8.

[12] K. Torres, F.J. Álvarez-Hornos, P. San-Valero, C. Gabaldón, P. Marzal, Granulation and microbial community dynamics in the chitosan-supplemented anaerobic treatment of wastewater polluted with organic solvents, Water Res. 130 (2018) 376-387, https://doi.org/10.1016/J.WATRES.2017.12.009.

[13] R.E. Rathbun, Transport, behavior, and fate of volatile organic compounds in streams, Crit. Rev. Environ. Sci. Technol. 30 (2000) 129-295, https://doi.org/ 10.1080/10643380091184183.

[14] M.P. Henry, B.A. Donlon, P.N. Lens, E.M. Colleran, Use of anaerobic hybrid reactors for treatment of synthetic pharmaceutical wastewaters containing organic solvents, J. Chem. Technol. Biotechnol. 66 (1996) 251-264, https://doi.org/ 10.1002/(SICI)1097-4660(199607)66:3<251::AID-JCTB496>3.0.CO;2-S.

[15] S. Raghuvanshi, B.V. Babu, Experimental studies and kinetic modeling for removal of methyl ethyl ketone using biofiltration, Bioresour. Technol. 100 (2009) 3855-3861, https://doi.org/10.1016/J.BIORTECH.2009.03.025.
[16] J.S. Devinny, M.A. Deshusses, T.S. Webster, Biofiltration for Air Pollution CONTROL, CRC Press, 1999.

[17] F. Costa, C. Quintelas, T. Tavares, Kinetics of biodegradation of diethylketone by Arthrobacter viscosus, Biodegradation 23 (2012) 81-92, https://doi.org/10.1007/ s10532-011-9488-7.

[18] C.-G. Lee, S. Lee, J.-A. Park, C. Park, S.J. Lee, S.-B. Kim, B. An, S.-T. Yun, S.-H. Lee, J.-W. Choi, Removal of copper, nickel and chromium mixtures from metal plating wastewater by adsorption with modified carbon foam, Chemosphere 166 (2017) 203-211, https://doi.org/10.1016/J.CHEMOSPHERE.2016.09.093.

[19] N. Fujiwara, H. Yamamoto, Evaluation of adsorption of organic solvents to modified hydrophobic silica adsorbents based on Hansen solubility parameter, Sep. Purif. Technol. 210 (2019) 907-912, https://doi.org/10.1016/J. SEPPUR.2018.08.034.

[20] E. Daneshvar, A. Vazirzadeh, A. Niazi, M. Sillanpää, A. Bhatnagar, A comparative study of methylene blue biosorption using different modified brown, red and green macroalgae - Effect of pretreatment, Chem. Eng. J. 307 (2017) 435-446, https:// doi.org/10.1016/J.CEJ.2016.08.093.

[21] V.S. Tran, H.H. Ngo, W. Guo, J. Zhang, S. Liang, C. Ton-That, X. Zhang, Typical low cost biosorbents for adsorptive removal of specific organic pollutants from water, Bioresour. Technol. 182 (2015) 353-363, https://doi.org/10.1016/j. biortech.2015.02.003.

[22] K. Vijayaraghavan, Y.S. Yun, Bacterial biosorbents and biosorption, Biotechnol. Adv. 26 (2008) 266-291, https://doi.org/10.1016/j.biotechadv.2008.02.002.

[23] C. Quintelas, F. Costa, T. Tavares, Bioremoval of diethylketone by the synergistic combination of microorganisms and clays: Uptake, removal and kinetic studies, Environ. Sci. Pollut. Res. 20 (2012) 1374-1383, https://doi.org/10.1007/s11356012-1055-1.

[24] A. Vinati, B. Mahanty, S.K. Behera, Clay and clay minerals for fluoride removal from water: A state-of-the-art review, Appl. Clay Sci. 114 (2015) 340-348, https:// doi.org/10.1016/J.CLAY.2015.06.013.

[25] T. Ngulube, J.R. Gumbo, V. Masindi, A. Maity, An update on synthetic dyes adsorption onto clay based minerals: A state-of-art review, J. Environ. Manage. 191 (2017) 35-57, https://doi.org/10.1016/J.JENVMAN.2016.12.031.

[26] M.K. Uddin, A review on the adsorption of heavy metals by clay minerals, with special focus on the past decade, Chem. Eng. J. 308 (2017) 438-462, https://doi. org/10.1016/J.CEJ.2016.09.029.

[27] S.C.R. Santos, R.A.R. Boaventura, Adsorption of cationic and anionic azo dyes on sepiolite clay: Equilibrium and kinetic studies in batch mode, J. Environ. Chem. Eng. 4 (2016) 1473-1483, https://doi.org/10.1016/J.JECE.2016.02.009.

[28] M. Sturini, A. Speltini, F. Maraschi, A. Profumo, S. Tarantino, A.F. Gualtieri, M. Zema, Removal of fluoroquinolone contaminants from environmental waters on sepiolite and its photo-induced regeneration, Chemosphere 150 (2016) 686-693, https://doi.org/10.1016/J.CHEMOSPHERE.2015.12.127.

[29] E. Padilla-Ortega, R. Leyva-Ramos, J.V. Flores-Cano, Binary adsorption of heavy metals from aqueous solution onto natural clays, Chem. Eng. J. 225 (2013) 535-546, https://doi.org/10.1016/J.CEJ.2013.04.011.

[30] Ö. Gök, A.S. Özcan, A. Özcan, Adsorption kinetics of naphthalene onto organosepiolite from aqueous solutions, Desalination 220 (2008) 96-107, https://doi. org/10.1016/J.DESAL.2007.01.025.

[31] D. Zadaka-Amir, N. Bleiman, Y.G. Mishael, Sepiolite as an effective natural porous adsorbent for surface oil-spill, Microporous Mesoporous Mater. 169 (2013) 153-159, https://doi.org/10.1016/J.MICROMESO.2012.11.002.

[32] D. Kovacević, J. Lemić, M. Damjanović, R. Petronijević, Đ. Janaćković, T. Stanić, Fenitrothion adsorption - desorption on organo - minerals, Appl. Clay Sci. 52 (2011) 109-114, https://doi.org/10.1016/J.CLAY.2011.02.006.

[33] S. Yu, L. Zhai, S. Zhong, Y. Qiu, L. Cheng, X. Ren, Synthesis and structural characterization of magnetite/sepiolite composite and its sorptive properties for Co (II) and Cd(II), J. Taiwan Inst. Chem. Eng. 59 (2016) 221-228, https://doi.org/ 10.1016/J.JTICE.2015.07.025.

[34] O. Duman, S. Tunç, T. Gürkan Polat, Adsorptive removal of triarylmethane dye (Basic Red 9) from aqueous solution by sepiolite as effective and low-cost adsorbent, Microporous Mesoporous Mater. 210 (2015) 176-184, https://doi.org/ 10.1016/J.MICROMESO.2015.02.040.

[35] R. Fu, Y. Yang, Z. Xu, X. Zhang, X. Guo, D. Bi, The removal of chromium (VI) and lead (II) from groundwater using sepiolite-supported nanoscale zero-valent iron (SNZVI), Chemosphere 138 (2015) 726-734, https://doi.org/10.1016/J. CHEMOSPHERE.2015.07.051.

[36] J. Huang, Z. Wu, L. Chen, Y. Sun, The sorption of Cd(II) and U(VI) on sepiolite: A combined experimental and modeling studies, J. Mol. Liq. 209 (2015) 706-712, https://doi.org/10.1016/J.MOLLIQ.2015.05.047.

[37] M. Cobas, L. Ferreira, M.A. Sanromán, M. Pazos, Assessment of sepiolite as a lowcost adsorbent for phenanthrene and pyrene removal: Kinetic and equilibrium studies, Ecol. Eng. 70 (2014) 287-294, https://doi.org/10.1016/J. ECOLENG.2014.06.014.

[38] I. Wilson, Applied Clay Mineralogy. Occurrences, processing and application of kaolins, bentonite, palygorskite-sepiolite, and common clays.: Haydn H. Murray. Developments in Clay Science, volume 2, Elsevier Science, Amsterdam, 2007, 180 + viii pp. ISBN-13: 978-0-44, Clays Clay Miner. 55 (2007) 644-645.

[39] E. Garciá-Romero, M. Suárez, On the Chemical Composition of Sepiolite and Palygorskite, Clays Clay Miner. 58 (2010) 1-20, https://doi.org/10.1346/ CCMN.2010.0580101.

[40] E. Ruiz-Hitzky, Molecular access to intracrystalline tunnels of sepiolite, J. Mater. Chem. 11 (2001) 86-91, https://doi.org/10.1039/b003197f.

[41] S. Yariv, Thermo-IR-spectroscopy analysis of the interactions between organic pollutants and clay minerals, Thermochim. Acta. 274 (1996) 1-35, https://doi. org/10.1016/0040-6031(95)02708-4. 
[42] M.H. El-Naas, J.A. Acio, A.E. El Telib, Aerobic biodegradation of BTEX: progresses and prospects, J. Environ. Chem. Eng. 2 (2014) 1104-1122, https://doi.org/ 10.1016/J.JECE.2014.04.009.

[43] M. Mojarad, A. Alemzadeh, G. Ghoreishi, M. Javaheri, Kerosene biodegradation ability and characterization of bacteria isolated from oil-polluted soil and water, J. Environ. Chem. Eng. 4 (2016) 4323-4329, https://doi.org/10.1016/J. JECE.2016.09.035.

[44] E. Kulczycki, F.G. Ferris, D. Fortin, Impact of cell wall structure on the behavior of bacterial cells as sorbents of cadmium and lead, Geomicrobiol. J. 19 (2002) 553-565, https://doi.org/10.1080/01490450290098586.

[45] J.A. Morlett-Chávez, J.Á. Ascacio-Martínez, A.M. Rivas-Estilla, J.F. VelázquezVadillo, W.E. Haskins, H.A. Barrera-Saldaña, K. Acuña-Askar, Kinetics of BTEX biodegradation by a microbial consortium acclimatized to unleaded gasoline and bacterial strains isolated from it, Int. Biodeterior. Biodegradation. 64 (2010) 581-587, https://doi.org/10.1016/J.IBIOD.2010.06.010.

[46] S.J. Edwards, B.V. Kjellerup, Applications of biofilms in bioremediation and biotransformation of persistent organic pollutants, pharmaceuticals/personal care products, and heavy metals, Appl. Microbiol. Biotechnol. 97 (2013) 9909-9921, https://doi.org/10.1007/s00253-013-5216-z.

[47] F. Costa, T. Tavares, Biosorption of nickel and cadmium in the presence of diethylketone by a Streptococcus equisimilis biofilm supported on vermiculite, Int. Biodeterior. Biodegradation. 115 (2016) 119-132, https://doi.org/10.1016/J. IBIOD.2016.08.004.

[48] F. Costa, T. Tavares, Sorption studies of diethylketone in the presence of $\mathrm{Al} \mathrm{3+,} \mathrm{Cd}$

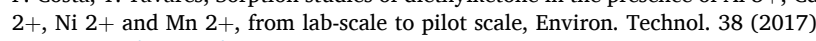
2811-2823, https://doi.org/10.1080/09593330.2016.1278462.

[49] J.V. Headley, J. Gandrass, J. Kuballa, K.M. Peru, Y. Gong, Rates of sorption and partitioning of contaminants in river biofilm, Environ. Sci. Technol. 32 (1998) 3968-3973, https://doi.org/10.1021/es9804991.

[50] J.R. Lawrence, G. Kopf, J.V. Headley, T.R. Neu, Sorption and metabolism of selected herbicides in river biofilm communities, Can. J. Microbiol. 47 (2001) 634-641.

[51] Z.D. Wen, W.M. Wu, N.Q. Ren, D.W. Gao, Synergistic effect using vermiculite as media with a bacterial biofilm of Arthrobacter sp. for biodegradation of di-(2ethylhexyl) phthalate, J. Hazard. Mater. 304 (2016) 118-125, https://doi.org/ 10.1016/j.jhazmat.2015.10.060.

[52] S. Upadhyay, A. Sinha, Role of microorganisms in Permeable Reactive Bio-Barriers (PRBBs) for environmental clean-up: A review, Glob. NEST J. 20 (2018) 269-280.

[53] R. Naidu, V. Birke, Permeable reactive barrier: Sustainable groundwater remediation, 2014. https://www.scopus.com/inward/record.uri?eid=2-s2.0-85 054609419\&partnerID =40\&md5=768d680495a545d092e8d9a97f625adc.

[54] R. Thiruvenkatachari, S. Vigneswaran, R. Naidu, Permeable reactive barrier for groundwater remediation, J. Ind. Eng. Chem. 14 (2008) 145-156, https://doi.org/ 10.1016/j.jiec.2007.10.001.

[55] B. Silva, E. Tuuguu, F. Costa, V. Rocha, A. Lago, T. Tavares, Permeable biosorbent barrier for wastewater remediation, Environ. Process. 4 (2017) 195-206, https:// doi.org/10.1007/s40710-017-0220-4.

[56] U. Kumarasinghe, K. Kawamoto, T. Saito, Y. Sakamoto, M.I.M. Mowjood, Evaluation of applicability of filling materials in permeable reactive barrier (PRB) system to remediate groundwater contaminated with $\mathrm{Cd}$ and $\mathrm{Pb}$ at open solid waste dump sites, Process Saf. Environ. Prot. 120 (2018) 118-127, https://doi.org/ 10.1016/j.psep.2018.09.003.

[57] F. Obiri-Nyarko, S.J. Grajales-Mesa, G. Malina, An overview of permeable reactive barriers for in situ sustainable groundwater remediation, Chemosphere 111 (2014) 243-259, https://doi.org/10.1016/j.chemosphere.2014.03.112.

[58] F. Costa, C. Quintelas, T. Tavares, An approach to the metabolic degradation of diethylketone (DEK) by Streptococcus equisimilis: Effect of DEK on the growth, biodegradation kinetics and efficiency, Ecol. Eng. 70 (2014) 183-188, https://doi org/10.1016/j.ecoleng.2014.05.009.

[59] F. Costa, T. Tavares, Pilot-scale sorption studies of diethylketone in the presence of $\mathrm{Cd}^{2+}$ and $\mathrm{Ni}^{2+}$, Environ. Technol. 40 (2019) 942-953, https://doi.org/10.1080/ 09593330.2017.1411979.

[60] F. Costa, T. Tavares, Bioremoval of $\mathrm{Ni}$ and $\mathrm{Cd}$ in the presence of diethylketone by fungi and by bacteria - A comparative study, Int. Biodeterior. Biodegrad. 120 (2017) 115-123, https://doi.org/10.1016/j.ibiod.2017.02.018.

[61] T. Lee, J. Kim, M.-J. Kim, H.W. Ryu, K.-S. Cho, Degradation characteristics of methyl ethyl ketone by Pseudomonas sp. KT-3 in liquid culture and biofilter, Chemosphere 63 (2006) 315-322.

[62] J.A. Riddick, W.B. Bunger, T.K. Sakano, Organic solvents: physical properties and methods of purification, fourth ed., John Wiley and Sons, New York, NY, United States, 1986 https://www.osti.gov/servlets/purl/6190969.

[63] Y.H. Yoon, J.H. Nelson, Application of gas adsorption kinetics I. A theoretical model for respirator cartridge service life, Am. Ind. Hyg. Assoc. J. 45 (1984) 509-516, https://doi.org/10.1080/15298668491400197.

[64] G. Yan, T. Viraraghavan, M. Chen, A new model for heavy metal removal in a biosorption column, Adsorpt. Sci. Technol. 19 (2001) 25-43, https://doi.org/ 10.1260/0263617011493953.

[65] S. Ayoob, A.K. Gupta, Sorptive response profile of an adsorbent in the defluoridation of drinking water, Chem. Eng. J. 133 (2007) 273-281, https://doi. org/10.1016/j.cej.2007.02.013.

[66] Q. Hu, Y. Xie, Z. Zhang, Modification of breakthrough models in a continuous-flow fixed-bed column: Mathematical characteristics of breakthrough curves and rate profiles, Sep. Purif. Technol. 238 (2020) 116399, https://doi.org/10.1016/j. seppur.2019.116399.

[67] L.M. Vera, D. Bermejo, M.F. Uguña, N. Garcia, M. Flores, E. González, Fixed bed column modeling of lead(II) and cadmium(II) ions biosorption on sugarcane bagasse, Environ. Eng. Res. 24 (2019) 31-37, https://doi.org/10.4491/ eer.2018.042.

[68] S. Guggenheim, M.P.S. Krekeler, Chapter 1 - The Structures and Microtextures of the Palygorskite-Sepiolite Group Minerals, in: E. Galàn, A.B.T.-D, C.S. Singer (Eds.), Dev. Palygorskite-Sepiolite Res., Elsevier, 2011: pp. 3-32. https://doi.org/ 10.1016/B978-0-444-53607-5.00001-3.

[69] L. Boudriche, R. Calvet, B. Hamdi, H. Balard, Effect of acid treatment on surface properties evolution of attapulgite clay: An application of inverse gas chromatography, Colloids Surfaces A Physicochem. Eng. Asp. 392 (2011) 45-54, https://doi.org/10.1016/j.colsurfa.2011.09.031.

[70] M.M. Correia dos Santos, V. Famila, M.L. Simões Gonçalves, A voltammetric study of the complexation of copper by the psychoactive compounds 1,4benzodiazepines, Electroanalysis 12 (2000) 216-222, https://doi.org/10.1002/ (SICI)1521-4109(200002)12:3<216::AID-ELAN216>3.0.CO;2-Q.

[71] T. Karlsson, P. Persson, U. Skyllberg, Complexation of copper(II) in organic soils and in dissolved organic matter - EXAFS evidence for chelate ring structures, Environ. Sci. Technol. 40 (2006) 2623-2628, https://doi.org/10.1021/es052211f.

[72] E. Galan, Properties and applications of palygorskite-sepiolite clays, Clay Miner. 31 (1996) 443-453, https://doi.org/10.1180/claymin.1996.031.4.01.

[73] H. Shariatmadari, A.R. Mermut, M.B. Benke, Sorption of selected cationic and neutral organic molecules on palygorskite and sepiolite, Clays Clay Miner. 47 (1999) 44-53, https://doi.org/10.1346/CCMN.1999.0470105.

[74] M. Polanyi, The Potential Theory of Adsorption, Science (80-.). 141 (1963) 1010 LP-1013. https://doi.org/10.1126/science.141.3585.1010.

[75] J.L. Sotelo, M.A. Uguina, J.A. Delgado, L.I. Celemin, Adsorption of methyl ethyl ketone and trichloroethene from aqueous solutions onto activated carbon fixed-bed adsorbers, Sep. Purif. Technol. 37 (2004) 149-160, https://doi.org/10.1016/j. seppur.2003.09.006.

[76] Y. Sardessai, S. Bhosle, Tolerance of bacteria to organic solvents, Res. Microbiol. 153 (2002) 263-268, https://doi.org/10.1016/S0923-2508(02)01319-0.

[77] H. Kusumawardhani, R. Hosseini, J.H. de Winde, Solvent Tolerance in Bacteria: Fulfilling the Promise of the Biotech Era? Trends Biotechnol. 36 (2018) 1025-1039, https://doi.org/10.1016/j.tibtech.2018.04.007.

[78] A. Inoue, K. Horikoshi, A Pseudomonas thrives in high concentrations of toluene, Nature 338 (1989) 264-266, https://doi.org/10.1038/338264a0.

[79] M.C. Reed, A. Lieb, H.F. Nijhout, The biological significance of substrate inhibition: A mechanism with diverse functions, BioEssays 32 (2010) 422-429, https://doi. org/10.1002/bies.200900167.

[80] P.K. Robinson, Enzymes: principles and biotechnological applications, Essays Biochem. 59 (2015) 1-41, https://doi.org/10.1042/bse0590001.

[81] A. Delle Site, Factors affecting sorption of organic compounds in natural sorbent/ water systems and sorption coefficients for selected pollutants. A review, J. Phys. Chem. Ref. Data. 30 (2001) 187-439, https://doi.org/10.1063/1.1347984.

[82] H.C. van der Mei, D. Naumann, H.J. Busscher, Grouping of streptococcus mitis strains grown on different growth media by FT-IR, Infrared Phys. Technol. 37 (1996) 561-564, https://doi.org/10.1016/S1350-4495(95)00080-1.

[83] S.L. Begg, The role of metal ions in the virulence and viability of bacterial pathogens, Biochem. Soc. Trans. 47 (2019) 77-87, https://doi.org/10.1042/ BST20180275.

[84] R.G. Piña, C. Cervantes, Microbial interactions with aluminium, Biometals 9 (1996) 311-316, https://doi.org/10.1007/BF00817932.

[85] S.B. Kurniawan, I.F. Purwanti, H.S. Titah, The effect of $\mathrm{pH}$ and aluminium to bacteria isolated from aluminium recycling industry, J. Ecol. Eng. 19 (2018) 154-161, https://doi.org/10.12911/22998993/86147.

[86] T.O. Ajiboye, O.A. Oyewo, D.C. Onwudiwe, Simultaneous removal of organics and heavy metals from industrial wastewater: A review, Chemosphere 262 (2021) 128379, https://doi.org/10.1016/j.chemosphere.2020.128379.

[87] S. Andini, R. Cioffi, F. Montagnaro, F. Pisciotta, L. Santoro, Simultaneous adsorption of chlorophenol and heavy metal ions on organophilic bentonite, Appl. Clay Sci. 31 (2006) 126-133, https://doi.org/10.1016/j.clay.2005.09.004.

[88] D. Lalhmunsiama, S.-M. Tiwari, Lee, Surface-functionalized activated sericite for the simultaneous removal of cadmium and phenol from aqueous solutions: Mechanistic insights, Chem. Eng. J. 283 (2016) 1414-1423, https://doi.org/ 10.1016/j.cej.2015.08.072.

[89] X. Hu, H. Ji, F. Chang, Y. Luo, Simultaneous photocatalytic $\mathrm{Cr}(\mathrm{VI})$ reduction and 2,4,6-TCP oxidation over g-C3N4 under visible light irradiation, Catal. Today. 224 (2014) 34-40, https://doi.org/10.1016/j.cattod.2013.11.038.

[90] S.G. Schrank, H.J. José, R.F.P. Moreira, Simultaneous photocatalytic Cr(VI) reduction and dye oxidation in a $\mathrm{TiO}_{2}$ slurry reactor, J. Photochem. Photobiol. A Chem. 147 (2002) 71-76, https://doi.org/10.1016/S1010-6030(01)00626-8.

[91] S. Kongjao, S. Damronglerd, M. Hunsom, Simultaneous removal of chromium and organic pollutants in tannery wastewater by electroprecipitation technique, Korean J. Chem. Eng. 24 (2007) 730-735, https://doi.org/10.1007/s11814-007-0034-6.

[92] V. Ya, N. Martin, Y.-H. Chou, Y.-M. Chen, K.-H. Choo, S.-S. Chen, C.-W. Li, Electrochemical treatment for simultaneous removal of heavy metals and organics from surface finishing wastewater using sacrificial iron anode, J. Taiwan Inst. Chem. Eng. 83 (2018) 107-114, https://doi.org/10.1016/j.jtice.2017.12.004.

[93] M.S. Wu, X. Xu, Q. Zhao, Z.Y. Wang, Simultaneous removal of heavy metals and biodegradation of organic matter with sediment microbial fuel cells, RSC Adv. 7 (2017) 53433-53438, https://doi.org/10.1039/C7RA11103G.

[94] Y. Li, B. Helmreich, Simultaneous removal of organic and inorganic pollutants from synthetic road runoff using a combination of activated carbon and activated lignite, Sep. Purif. Technol. 122 (2014) 6-11, https://doi.org/10.1016/j. seppur.2013.10.025. 